\title{
REVIEW
}

\section{Sex differences in vascular function: implication of endothelium-derived hyperpolarizing factor}

\author{
Inmaculada C Villar, Adrian J Hobbs and Amrita Ahluwalia ${ }^{1}$ \\ Department of Pharmacology, University College London, Medical Sciences Building, Gower Street, London WC1E 6BT, UK \\ ${ }^{1}$ Clinical Pharmacology, Barts and The London Medical School, William Harvey Research Institute, Queen Mary, University of London, Charterhouse Square, \\ London EC1M 6BQ, UK \\ (Correspondence should be addressed to A Ahluwalia; Email: a.ahluwalia@qmul.ac.uk)
}

\begin{abstract}
The vascular endothelium plays a crucial role in the regulation of vascular homeostasis by controlling vascular tone, coagulation, and inflammatory responses. These actions are exerted by endothelial factors including nitric oxide, prostacyclin, and endothelium-derived hyperpolarizing factor (EDHF). The greater incidence of cardiovascular disease (CVD) in men and postmenopausal women compared with premenopausal women implies a vasoprotective phenotype of females, which may be influenced by sex hormones. These hormones, particularly estrogen, have modulatory effects on the endothelium and circulating cells that have been implicated in vascular inflammation and in the development
\end{abstract}

of CVD. EDHF seems to be the predominant endothelial factor in the resistance vasculature of females and this mediator could afford the beneficial cardiovascular risk profile observed in premenopausal woman. In this review, we discuss sex differences in EDHF biology and how sex hormones can modulate EDHF responses. We also review the implication of sex hormone-dependent regulation of EDHF in inflammatory processes, platelet function, and repair after vascular damage, each of which have a critical role in several aspects of the pathogenesis of CVD.

Journal of Endocrinology (2008) 197, 447-462

\section{Introduction}

A lower incidence of cardiovascular disease (CVD) in premenopausal women compared with age-matched male counterparts and postmenopausal women (Lerner \& Kannel 1986, Barrett-Connor 1997) suggests that ovarian hormones underlie a protective effect on the cardiovascular system. Indeed, a wealth of evidence from observational and experimental studies, in both animals and humans, supports the concept of a protective effect of estrogens in the cardiovascular system. Thus, it was wholly unexpected when the Women's Health Initiative (WHI), a large-scale trial with menopausal hormone treatment (MHT), often also described as hormone replacement therapy (HRT) in postmenopausal women aged 50-79 was terminated early due to a surprising increase in the incidence of cardiovascular events (The Women's Health Initiative Steering Committee 2004). However, further secondary analysis of the WHI data sheds some light on the apparent paradoxical findings (Hsia et al. 2006); whilst overall there was an increase in events, separation of the cohorts by age demonstrated a significant protection of MHT in women with fewer menopausal years. This issue was later confirmed in a following ancillary study measuring coronary artery calcification in women aged 50-59 (Manson et al. 2007). It is clear that estrogens offer a number of protective beneficial effects; however, MHT is complicated by a number of detrimental actions that depend upon age, the type of hormone preparation, and mode of application, issues that all influence the target as well as the mechanism of action of estrogen. Understanding the molecular pathways that underlie the beneficial effects of estrogens may, therefore, identify novel strategies that could be taken to harness the therapeutic potential of MHT safely.

Numerous studies have been conducted in an attempt to more clearly understand the protective effects of estrogens in the cardiovascular system, and a number of targets/pathways/ mediators have been proposed (Mendelsohn \& Karas 1999, 2005, Orshal \& Khalil 2004, Villar et al. 2006). Perhaps, of all of the effects that have been attributed to estrogens, there is one particular characteristic of these sex hormones, which has been demonstrated repeatedly to contribute to the beneficial effects in the cardiovascular system i.e. estrogeninduced or enhanced activation of the endothelium. It is now accepted that changes in endothelial function are instrumental 
in the vascular inflammation that is an early and crucial event in the pathogenesis of a number of cardiovascular disorders (e.g. atherosclerosis, ischemia/reperfusion (I/R) injury). Endothelium-derived factors not only alter the tone and growth of the underlying smooth muscle, but also regulate the reactivity of circulating white cells, erythrocytes, and platelets and govern vascular permeability. Indeed, the endothelium is critical in maintaining an anti-inflammatory, and thereby antiatherogenic, influence on the blood vessel wall. In the early stages of several inflammatory CVDs, a switch in endothelial phenotype occurs from a protective anti-inflammatory to a pro-inflammatory phenotype, characterized by the production of pro-inflammatory mediators. Much evidence supports the thesis that estrogens upregulate the synthesis, release, and activity of protective endothelial factors and suppress the expression of pathogenic mediators by the endothelium and, thereby, preventing this apparent change in phenotype. The majority of these actions have been attributed to estrogens acting on the estrogen receptors (ER) $\alpha$ and $\operatorname{ER} \beta$, both of which have been identified in the vasculature (Mendelsohn \& Karas 2005). More importantly, it is this protective action that is thought to underlie the protection of females from CVD (Villar et al. 2006).

Perhaps the most-described phenomenon relating to estrogen-induced changes in endothelial activity is the impact these hormones have on vascular tone mediated via stimulation of the release of endothelium-derived vasodilators. The most significant vasodilator factors that the endothelium releases are prostacyclin $\left(\mathrm{PGI}_{2}\right.$; Moncada et al. 1976), nitric oxide (NO; Ignarro et al. 1987, Palmer et al. 1987, Furchgott \& Vanhoutte 1989, Moncada \& Higgs 2006), and endothelium-derived hyperpolarizing factor (EDHF; Chen et al. 1988, Griffith 2004, Ahluwalia \& Hobbs 2005). The biological activity and functions of endothelium-derived $\mathrm{NO}$ and $\mathrm{PGI}_{2}$ in the cardiovascular system are well established and include not only vasodilatation but also inhibition of platelet aggregation, leukocyte recruitment, and smooth muscle growth (Moncada \& Vane 1981, Moncada \& Higgs 1991, 2006). Indeed, both of these factors have been identified as important targets for estrogen activity and there are many recent excellent reviews that the reader is referred to on this matter (Orshal \& Khalil 2004, Mendelsohn \& Karas 2005, Villar et al. 2006). However, the nature and role(s) of EDHF in the vasculature remain controversial and whether estrogens modulate its expression and function is also uncertain. Recently, we have proposed that the functional remit of EDHF may extend beyond its vasodilator effects and that, as its fellow endothelial vasodilators, it may also inhibit leukocyte recruitment and platelet reactivity and thereby provide a compensatory pathway in situations (such as CVD) where endothelial $\mathrm{NO}$ or $\mathrm{PGI}_{2}$ synthesis/activity is suppressed (Ahluwalia \& Hobbs 2005). Indeed, this is particularly relevant when one considers that basal $\mathrm{NO}$ synthesis is thought to inhibit EDHF release/activity and that EDHF responses are often exposed in an environment where NO synthesis has been repressed (Bauersachs et al. 1996). This review will describe and discuss the evidence investigating the possibility that alterations in EDHF may underlie the sex differences in CVD and whether estrogens are implicated.

\section{EDHF}

EDHF hyperpolarizes and relaxes vascular smooth muscle and, thereby, plays a fundamental role in the regulation of vascular tone (Garland et al. 1995, Busse et al. 2002). The physiological significance of EDHF is emphasized by the finding that as one descends the vascular tree, the role of $\mathrm{NO}$ diminishes whereas the influence of EDHF increases (Shimokawa et al. 1996) implicating EDHF in the control of local blood flow and, therefore, determination of peripheral resistance and systemic blood pressure. It is now accepted that EDHF release from the endothelial cell occurs following the opening of endothelial small conductance calcium-activated potassium channel $\left(\mathrm{SK}_{\mathrm{Ca}}\right)$ and intermediate conductance calcium-activated potassium channel ( $\mathrm{IK}_{\mathrm{Ca}}$; Busse et al. 2002). Its activity, on the vascular smooth muscle, involves activation of the $\mathrm{Na}^{+} / \mathrm{K}^{+}$-ATPase and the inwardly rectifying potassium channel $\left(\mathrm{K}_{\mathrm{IR}}\right)$. However, the identity of this factor, or factors, remains uncertain. Since the first report of EDHF (Chen et al. 1988), several putative candidate factors have been proposed including hydrogen peroxide $\left(\mathrm{H}_{2} \mathrm{O}_{2}\right.$; Shimokawa \& Morikawa 2005), metabolites of arachidonic acid such as epoxyeicosatrienoic acids (EETs; Fleming \& Busse 2006), potassium ions (Edwards \& Weston 2004), and most recently C-type natriuretic peptide (CNP; Ahluwalia \& Hobbs 2005); alternatively, EDHF may be an electrical coupling through myoendothelial junctions (Feletou \& Vanhoutte 2006). Yet, none have been confirmed as a universal EDHF (Feletou \& Vanhoutte 2006). Indeed, this 'EDHF heterogeneity' has led to the proposal that multiple EDHFs exist and that its identity varies between organs and species studied. Moreover, the release of more than one EDHF in a given vascular bed also seems to occur (Busse et al. 2002, Villar et al. 2007b). As a consequence of this intra- and inter-tissue and species heterogeneity, it is unlikely that a single unique EDHF exists (unlike the role of NO as EDRF). Furthermore, whether sex differences in EDHF activity might underlie the differences in susceptibility to CVD is unclear. In light of this, we have reviewed the evidence investigating this possibility focusing on the role that EDHF might play in mediating the influence of the endothelium on vascular reactivity in terms of vascular tone, leukocyte recruitment, platelet activation, and vessel repair.

\section{Sex differences in vascular tone: $E D H F$}

Endothelium-derived factors, particularly NO, play an important role in the paracrine regulation of vascular tone (Orshal \& Khalil 2004, Villar et al. 2006). However, there is a growing body of evidence suggesting that EDHF is also 
crucial in this modulation, especially given the fact that in the resistance vasculature the predominant mediators implicated in endothelium-dependent relaxation in males are NO and $\mathrm{PGI}_{2}$, whereas in females it is EDHF (McCulloch \& Randall 1998, Pak et al. 2002, Scotland et al. 2005b).

We developed an endothelial NO synthase/cyclooxygenase 1 (eNOS/COX-1) double knockout (dKO) mouse, or 'EDHF mouse', to explore the potential role of EDHF in vascular function. This model is unique because it circumvents the notorious lack of selective EDHF antagonists and the possible complications seen when using the classical inhibitors, L-nitro-arginine-methyl ester and indomethacin, to remove $\mathrm{NO}-$ and $\mathrm{PGI}_{2}$-dependent relaxations (Chauhan et al. 2003a). In these animals, we have shown that males are hypertensive whereas females are normotensive. Moreover, the administration of the endothelium-dependent dilator bradykinin, to female dKOs, causes a dose-dependent decrease in arterial blood pressure, while this vasoactive peptide has no effect in the male $\mathrm{dKO}$ animals; this result was mirrored in mesenteric arteries in vitro, where endotheliumderived relaxation stimulated by acetylcholine was significantly greater in females. Since EDHF plays a more prominent role in endothelium-dependent relaxation of resistance versus conduit arteries (Shimokawa et al. 1996), data from the EDHF mouse suggests that sex hormones regulate EDHF activity and that this may play a critical role in the maintenance of physiological levels of blood pressure and endothelial function in females (Scotland et al. 2005b). Consequently, enhanced EDHF function in females compared with males (McCulloch \& Randall 1998, Pak et al. 2002, Scotland et al. 2005b) might afford the cardioprotective phenotype of females.

It is thought that estrogen activity underlies this sex difference in the prevalence of EDHF responses. Indeed, an estrogen deficit in animals, achieved by ovariectomy, reduces EDHF responses induced by several different stimuli and this effect is reversed by treatment with $17 \beta$-estradiol (Huang et al. 2001, Liu et al. 2001, 2002, Chataigneau et al. 2004, $\mathrm{Xu}$ et al. 2005). Also, EDHF responses are reduced during periods of the estrus cycle when estrogen levels are lowest (Lucca et al. 2000). In contrast, recent studies have indicated that ovariectomy does not affect the magnitude of acetylcholine-mediated relaxation in the rat mesenteric artery (Chataigneau et al. 2004, Nawate et al. 2005). However, when the EDHF- and NO-mediated components of this endothelium-dependent relaxation were examined separately, it was observed that while the magnitude of the response remained relatively unaltered, ovariectomy reduced the magnitude of the EDHF-mediated component but enhanced the NO-mediated component of the response (Chataigneau \& Schini-Kerth 2005), supporting a role for estrogen in regulation of EDHF-mediated vasorelaxation. However, these findings, especially with respect to the effect on NO-mediated responses, should be interpreted with caution since a substantial body of evidence clearly demonstrates that estrogens enhance NO production within blood vessels, indeed many of the beneficial actions of estrogens have been attributed to this very characteristic (for reviews, see Orshal \& Khalil 2004, Mendelsohn \& Karas 2005, Murphy \& Steenbergen 2007). Moreover, in middleaged rats, acetylcholine-mediated hyperpolarization is upregulated in females and this effect is reduced by ovariectomy and recovered by $17 \beta$-estradiol treatment (Sakuma et al. 2002). Interestingly, the EDHF-mediated component of acetylcholine-induced vasodilatation is enhanced after myocardial infarction only in females (Csanyi et al. 2006), a finding that perhaps hints at an endogenous EDHFmediated damage-limiting mechanism. The exact nature of the mechanisms underlying the enhanced EDHF vasoactivity observed in females is by no means clear, but we have attempted to consider the main proposed pathways below in terms of putative EDHF candidates.

Gap junctions Gap junctions facilitate chemical and electrical communication between coupled cells (Sandow \& Hill 2000). There is substantial support for the concept that EDHF, rather than being a 'factor' per se, might simply represent the transfer of hyperpolarizing current from the endothelial cell to the smooth muscle, a phenomenon facilitated by the myoendothelial gap junction (Griffith 2004). This thesis is supported by several studies using blockers of gap junctional communication that have demonstrated selective inhibition of vasodilator responses attributable to EDHF (Griffith 2004). These junctional structures are formed by intracellular channels that are composed of different members of the connexin $(\mathrm{Cx})$ protein family (Griffith 2004). Endothelial cells express Cx37, Cx40, and $\mathrm{Cx} 45$, whereas smooth muscle cells express $\mathrm{Cx} 43$ and Cx45 (Gabriels \& Paul 1998, Theis et al. 2001). Myoendothelial gap junctions occur in greater density in resistance compared with conduit arteries and, consequently, it has been suggested that the gap junctions may play a role in the hormonal modulation of vascular relaxation (as an EDHF candidate). Indeed, it has been proposed that a decrease in the vascular expression of $\mathrm{Cx} 43$ alone or concomitantly with Cx40 could afford the reduction in EDHF-mediated responses in rat mesenteric arteries of ovariectomized rats (Liu et al. 2002, Xu et al. 2002, Nawate et al. 2005); this was substantiated by the observation that when animals were treated with $17 \beta$-estradiol, all responses were normalized (Chataigneau \& Schini-Kerth 2005, Nawate et al. 2005). In addition, it has been suggested that the increased EDHFmediated relaxation, associated with pregnancy in rats and humans (Pascoal \& Umans 1996, Gerber et al. 1998, Kenny et al. 2002), is in part due to enhanced gap junctional communication at least in response to bradykinin in subcutaneous small arteries of pregnant women (Luksha et al. 2004, Lang et al. 2007). However, in rat middle cerebral arteries myoendothelial gap junction frequency does not correlate with the reduced EDHF responses observed in females compared with males (Sokoya et al. 2007). 
C-type natriuretic peptide $\mathrm{CNP}$ has been described as an EDHF in the mesenteric and coronary circulation (Barton et al. 1998, Chauhan et al. 2003b, Hobbs et al. 2004). This peptide belongs to a family of structurally similar vasoactive peptides that have vasodilator and diuretic actions and play an important role in maintenance of blood volume and blood pressure (Levin et al. 1998, Fowkes \& McArdle 2000, Scotland et al. 2005a). This peptide is widely expressed throughout the vasculature, being found in particularly high concentrations in vascular endothelial cells (Stingo et al. 1992) where it plays a role in the local regulation of vascular tone. Its biological effects are mediated not only via natriuretic peptide receptor (NPR)-B (in a cGMP-dependent manner), but also via NPR-C, which is classically termed a 'clearance receptor' that removes natriuretic peptides from the circulation. However, this receptor also possesses an intracellular G-protein-binding domain and can couple to Gi/o G-proteins (Anand-Srivastava et al. 1996) and this is involved in part in a recently elucidated signal transduction pathway(s) underlying the vasorelaxant activity of CNP and EDHF (Villar et al. 2007b).

Interestingly, previous studies have identified sex differences in the vasorelaxant activity of CNP. In porcine coronary arteries, relaxations to $\mathrm{CNP}$ are greater in female than in males (Barber et al. 1998) and the highest CNP mRNA concentrations in mice are found in the uterus and ovaries, and this expression is increased further still during pregnancy, a period of high estrogen concentration (Stepan et al. 2000). Moreover, 17 $\beta$-estradiol increases CNP gene expression in the uterus of ovariectomized mice (Acuff et al. 1997) and in rats, the estrous cycle regulates CNP content in both the ovary and uterus (Huang et al. 1996). Taken together, these studies suggest that modulation of CNP release/activity by sex hormones may contribute to the enhanced EDHF activity in females.

Hydrogen peroxide Several studies have suggested that $\mathrm{H}_{2} \mathrm{O}_{2}$ acts as an EDHF in animal and human blood vessels (Matoba et al. 2000, 2002, Miura et al. 2003). In endothelial cells, eNOS and some oxidases including cytochrome P450 (CYP) epoxygenases, cyclooxygenases, lipoxygenases, $\mathrm{NAD}(\mathrm{P}) \mathrm{H}$, and xanthine oxidase can be sources of superoxide, which is dismutated spontaneously, or by superoxide dismutase (SOD), to $\mathrm{H}_{2} \mathrm{O}_{2}$ (Fleming et al. 2001, Shimokawa \& Matoba 2004). This dismutation is prinicipally a mechanism utilized within the vasculature to inactivate superoxide and in this way sustain an antioxidant status. However, it is also clear that $\mathrm{H}_{2} \mathrm{O}_{2}$ per se has multiple functions within the vasculature, not only as a potentially damaging reactive oxygen species, but also possibly as a physiological regulator of vascular reactivity including the regulation of vascular tone (Miller et al. 2007a). Furthermore, there is some evidence to suggest that estrogens as well as enhancing antioxidant status by elevating SOD levels also simultaneously provide a vasodilator. It is thought that endothelial $\mathrm{Cu} / \mathrm{Zn}$ SOD plays a principal role in the hyperpolarization responses elicited by $\mathrm{H}_{2} \mathrm{O}_{2}$ (Morikawa et al. 2003, Shimokawa \& Matoba 2004) and several studies have identified sex differences in $\mathrm{H}_{2} \mathrm{O}_{2}$ responses. For example in $\mathrm{Cu} / \mathrm{Zn}$ SOD KO mice, myogenic tone is increased in arteries of females compared with male controls (Veerareddy et al. 2004). This apparent difference in the $\mathrm{H}_{2} \mathrm{O}_{2}$-dependent regulation of tone may be a consequence of enhanced synthesis since physiological concentrations of estrogen stimulate the formation of reactive oxygen species, predominantly $\mathrm{H}_{2} \mathrm{O}_{2}$, in endothelial cells. The endothelial oxidases involved in this process appear to be within the mitochondrial respiratory chain and xanthine oxidase (Felty et al. 2005, Felty 2006). However, it is likely that alterations in direct synthesis are not the sole mechanism and that estrogens also effect changes in dismutation of free radicals and therefore $\mathrm{H}_{2} \mathrm{O}_{2}$ generation. In support of such a mechanism is the finding that ovariectomy reduces $\mathrm{Cu} / \mathrm{Zn} \mathrm{SOD}$ protein expression in mice; an effect reversed following in vivo estradiol supplementation (Muller-Delp et al. 2003). However, in contrast are studies in the cerebral circulation of the rat that show no difference in SOD expression between male and female animals (Miller et al. 2007a,b).

Epoxyeicosatrienoic acids EETs, generated following metabolism of arachidonic acid by CYP epoxygenases, have been considered as potential candidates for EDHF due to their capacity to hyperpolarize and relax vascular smooth muscle cells by activating $\mathrm{K}_{\mathrm{Ca}}$ channels (Campbell et al. 1996, Campbell \& Falck 2007). Accordingly, sex differences in the vasoactive responses to endogenously generated EETs have been reported. In particular, it has been proposed that EETs mediate flow-induced dilatation in gracilis arterioles of female rats and mice, while, in contrast, this response is largely mediated by NO in arterioles of male animals (Wu et al. 2001, Huang et al. 2005). Although, in male mice expressing depressed eNOS expression, flow-induced dilatation remains unchanged; an effect that the authors propose to be due to compensatory upregulation of EET synthesis (Sun et al. 2007). These responses in gracilis arterioles of female mice are dependent on estrogen since EET-mediated flow-induced dilatation is abolished by ovariectomy and restored by estrogen replacement (Huang et al. 2001). This effect of estrogen is likely due to an upregulation in endothelial EET synthesis, rather than alterations in the sensitivity of vascular smooth muscle to these eicosanoids, since the enhanced vasodilator response to shear stress is associated with upregulation of CYP activity (Huang et al. 2004). Furthermore, recent studies, in human coronary arterioles, suggest that exogenously applied EETs induce dilatation that is unaffected by sex (Larsen et al. 2006). Thus, it seems likely that at least a component of estrogen-mediated enhancement of EDHF activity relates to alterations in CYP epoxygenase activity.

\section{Sex differences in vascular inflammation}

There are several studies supporting the thesis that sex hormones modulate the initiation and progression of inflammatory responses in females. Indeed, female sex and 
estrogens appear to be protective against a range of inflammatory diseases including multiple sclerosis and Alzheimer's to atherosclerosis (Nilsson 2007). Similarly, estrogens appear to suppress the inflammatory responses in experimental models of inflammation in both in vivo and in vitro systems (Nathan et al. 1999, Mukherjee et al. 2002, Card et al. 2006). A significant proportion of this antiinflammatory activity has been attributed to alterations in $\mathrm{NO}$ synthesis and activity (Thompson \& Khalil 2003, Orshal \& Khalil 2004); however, EDHF has also been proposed to play a role. For example, EDHF controls blood flow and, therefore, levels of shear stress at the blood vessel wall. These hemodynamic forces regulate endothelial activation (Malek et al. 1999) and consequently moderate leukocyte recruitment, platelet activation, and vessel repair mechanisms. Therefore, at atheroma-prone sites, where low levels of shear stress have been implicated in pathogenesis, shear stressregulated EDHF-dependent responses may be important in limiting, or indeed preventing, atherosclerotic events (Selemidis \& Cocks 2002). In the next section, we have examined the possibility that, just as endothelium-derived NO, EDHF may be more than simply a vasodilator (Ahluwalia \& Hobbs 2005). In particular, we have discussed the possibility that EDHF might play an essential role in maintaining the anti-inflammatory phenotype of the endothelial cell and thereby limiting vascular inflammation and progression of CVD. We have specifically focused on the role of EDHF in leukocyte recruitment, platelet activation, and vessel repair; all important mechanisms involved particularly in the progression of atherosclerosis (Libby 2002).

\section{Sex differences in leukocyte recruitment}

Leukocyte recruitment is an early and pivotal event in vascular inflammatory responses that is prompted by the expression of, and consequent interaction between, leukocyte and endothelial cell adhesion molecules. The sequential steps of rolling, adhesion, and transmigration mediate this process via the activity of specific families of adhesion molecules that characterize each step (Butcher 1991, Springer 1994, Rao et al. 2007, Zarbock \& Ley 2008). There is some evidence, from diverse animal models of inflammation, to suggest the existence of sex hormone-dependent male/female differences in leukocyte recruitment (Squadrito et al. 1997, Simoncini et al. 2000b, Eckhoff et al. 2002) with evidence supporting the thesis that estrogens have the capacity to alter all stages of the recruitment process.

Recently, we have shown that female mice exhibit reduced basal and interleukin (IL)-1 $\beta$-stimulated leukocyte rolling compared with males (Villar et al. 2007b), although whether ovarian hormones underlie this effect is currently unknown. However, estrogen inhibits the leukocyte rolling response to diverse inflammatory stimuli including I/R injury, where, for example, estrogen treatment prevents leukocyte rolling in the mouse cremaster (Prorock et al. 2003).
Similarly, there is supporting evidence for an inhibitory effect of estrogen on the firm adherence of leukocytes. In hypercholesterolemic rabbits, monocyte adhesion to endothelial cells and transendothelial migration is retarded in females compared with male animals; an effect likely due to female sex hormone activity since ovariectomy enhances cell adhesion while supplementation of these animals with $17 \beta$-estradiol restores protection (Nathan et al. 1999). This protective effect of sex is reproduced in other inflammatory models, again including ischemia-reperfusion injury, where, for instance, female sex hormones decrease leukocyte adhesion in response to a transient forebrain ischemic insult (Santizo et al. 2000). In addition, 17 $\beta$-estradiol reduces the granulocyte and monocyte/macrophage populations of injured vessels and limits leukocyte entry from adventitial/ periadventitial tissues into injured vessels, thereby reducing the neointimal response to vascular injury (Xing et al. 2004).

Mechanistically, there is much evidence supporting the theory that estrogen-induced inhibition of leukocyte recruitment is due to an effect of female sex hormones on endothelial adhesion molecule expression and activity. $17 \beta$ estradiol suppresses monocyte endothelial adhesion stimulated by diverse stimuli including cytokines (Mikkola \& St Clair 2002, Mori et al. 2004), LPS (Gao et al. 2006), and oxidized LDL (Suzuki et al. 1997), and various endothelial adhesion molecules have been implicated including intercellular and vascular adhesion molecule-1 (ICAM-1 and VCAM-1), P- and E-selectin in human (Caulin-Glaser et al. 1996, Simoncini et al. 2000a), and rabbit endothelial cells (Nathan et al. 1999). However, conversely $17 \beta$-estradiol and progesterone increase adhesion of leukocytes to human umbilical vein endothelial cells (HUVEC), stimulated by tumor necrosis factor- $\alpha(\mathrm{TNF}-\alpha)$ by increasing expression of E-selectin, ICAM-1, and VCAM-1 (Cid et al. 1994). In addition, there is some evidence suggesting that male sex hormones exert inhibitory effects on leukocyte recruitment. Indeed, testosterone inhibits VCAM-1 mRNA and protein expression in HUVECs, although this action is dependent upon conversion to $17 \beta$-estradiol via aromatase activity, an enzyme present in endothelial cells (Mukherjee et al. 2002). There is also evidence to suggest that rather than directly affecting adhesion molecule expression, estrogens suppress the expression of specific chemokines (chemoattractant cytokines) that are produced by endothelial cells among other cell types. In a model of balloon-induced vascular injury in rats MCP-1 and CINC-1, chemoattractants for monocytes and neutrophils respectively (Miller et al. 2004) were suppressed. Furthermore, in animal models of atherosclerosis, MCP-1 levels, which have been implicated in disease progression (Libby 2002), are reduced in females in an estrogendependent manner, an effect correlated with decreased atheroma formation (Pervin et al. 1998). Exactly what role EDHF might play, with respect to each of the proposed candidates in mediating these sex-dependent inhibitory effects is discussed below. 
Gap junctions Besides the implication of gap junction in controlling vascular tone, these cellular connections also play a role in leukocyte recruitment. It has been reported that neutrophils, monocytes, and lymphocytes can form functional gap junction channels and this coupling, primarily mediated by the ubiquitously expressed $\mathrm{Cx} 43$, is inhibited by pharmacological blockers of gap junctions and stimulated by inflammatory mediators including LPS (Oviedo-Orta \& Howard Evans 2004). It is thought that the formation of these junctions facilitates intercellular communication not only via transfer of current between cells, but also by permitting the transfer of small molecules including ions, second messengers, and small peptides (see Neijssen et al. 2007) Functionally, leukocyte-endothelial interaction and transendothelial migration of leukocytes also appear to involve activity of gap junctions (Neijssen et al. 2007). In particular, $\mathrm{Cx} 43$ expression of leukocytes is associated with the adherence and recruitment of leukocytes stimulated by LPS or ischemia-reperfusion injury (Jara et al. 1995).

The exact functional role of these gap junctions with respect to cellular recruitment appears to vary dependent on the cell type. For example, inhibition of gap junctions increases neutrophil but decreases monocyte migration (Wong et al. 2004). The inhibitory effect of gap junction expression on PMN migration appears to involve heterotypic (i.e. more than one type of connexin) cell communication and, in particular, has been attributed to gap junctions comprised $\mathrm{Cx} 40$ and Cx37 (Zahler et al. 2003) and Cx43 (Parthasarathi et al. 2006). More recently, the functional consequences of this inhibitory activity have been highlighted in APOE KO mice (a model of atherosclerosis) also deleted for $\mathrm{Cx} 37$, where lesion formation was substantially enhanced (Wong et al. 2006). Several studies clearly demonstrate that the expression of $\mathrm{Cx} 37, \mathrm{Cx} 40$, and $\mathrm{Cx} 43$ are all regulated by estrogen (Di et al. 2001, Punyadeera et al. 2005), and it is likely that this regulation, to some extent, underlies the effects of female sex hormones on leukocyte recruitment, such that the enhancement of expression of the gap junctions may in part mediate the decreased inflammatory cell recruitment evident in female animal models of inflammation.

C-type natriuretic peptide Some evidence implicates CNP in inflammatory events since plasma levels of this peptide are elevated in patients with septic shock (Hama $e t$ al. 1994) and anti-inflammatory effects of CNP have been described in acute myocarditis (Obata et al. 2007). Our in vivo experiments have demonstrated that CNP inhibits leukocyte rolling in mice with elevated basal leukocyte activation induced by IL-1 $\beta$ and histamine; this effect appears to be mediated via attenuation of P-selectin expression (Scotland et al. 2005c). In addition, adenovirus mediated-expression of human CNP and suppresses ICAM-1 and VCAM-1 expression and macrophage infiltration in balloon-injured rabbit carotid arteries (Qian et al. 2002). Moreover, this endothelium-derived mediator suppresses infarct size and myocardial dysfunction in isolated mouse hearts (Hobbs et al. 2004). Whether the differences in inflammation prevalent in females are due to an enhancement of CNP synthesis or activity is for the present unknown.

Hydrogen peroxide Several studies have shown that $\mathrm{H}_{2} \mathrm{O}_{2}$ possesses pro-inflammatory properties. For example, experimental data suggest that endogenous $\mathrm{H}_{2} \mathrm{O}_{2}$ production induced in $\mathrm{I} / \mathrm{R}$ and following inflammatory stimuli contributes to the consequent associated injury (Granger 1988). $\mathrm{H}_{2} \mathrm{O}_{2}$ also promotes neutrophil adhesion to endothelial cells and this effect appears to be mediated by P-selectin (Lewis et al. 1988, Patel et al. 1991). In addition, it has been suggested that increased $\mathrm{H}_{2} \mathrm{O}_{2}$ production contributes to endothelial NF- $\kappa \mathrm{B}$ activation in aged rat arteries (Ungvari et al. 2007) and induces TNF- $\alpha$ mRNA in HUVECs (Valen et al. 1999). Moreover, $\mathrm{H}_{2} \mathrm{O}_{2}$ enhances the expression of both CD11b and CD18 on eosinophils (Nagata et al. 2000). It has also been reported that $\mathrm{H}_{2} \mathrm{O}_{2}$ plays an important role in cardioprotection against coronary I/R injury in vivo (Yada et al. 2006). While this latter evidence supports an antiinflammatory role for $\mathrm{H}_{2} \mathrm{O}_{2}$, a greater body of evidence indicates a pro-inflammatory function for this molecule. These findings suggest that $\mathrm{H}_{2} \mathrm{O}_{2}$ is unlikely to underlie the beneficial effects on inflammation/leukocyte recruitment associated with EDHF.

Epoxyeicosatrienoic acids EETs have been described as powerful anti-inflammatory mediators since they inhibit NF$\kappa \mathrm{B}$ and I $\mathrm{\kappa B}$ kinase and, consequently, prevent leukocyte adhesion to the vascular wall (Node et al. 1999). Moreover, at physiological concentrations, these agents inhibit cytokineinduced VCAM-1, ICAM, and E-selectin expression and the activity of pro-inflammatory enzymes including inducible NOS and COX-2 in human endothelial cells (Node et al. 1999, Campbell 2000). Overexpression of the EET-synthesizing CYP 2J2 also has similar effects and can protect against I/R injury in vitro and in vivo (Spiecker \& Liao 2006). EETs also decrease pro-inflammatory prostaglandin levels in porcine aortic smooth muscle cells by competitive inhibition of COX enzymes (Fang et al. 1998) and attenuate cigarette smokeinduced lung inflammation and the accumulation of neutrophils, alveolar macrophages, and lymphocytes in bronchoalveolar fluid (Smith et al. 2005). Recently, it has been reported that the anti-inflammatory effects of EETs on endothelial cells may be mediated by $\alpha / \gamma$ peroxisome proliferator-activated receptor (PPAR; Liu et al. 2005, Wray \& Bishop-Bailey 2007). Sex hormones might operate via such a pathway since it has been demonstrated that estrogen regulates PPAR expression (Campbell et al. 2003, Faddy et al. 2006). Although, more recent evidence in isolated arteries suggest that while PPAR $\gamma$ might enhance endothelial vasodilator release in conduit vessels, in resistance arteries activation of this receptor is inhibitory for EDHF release (O'Sullivan et al. 2006). Thus, EETs clearly mediate a number of anti-inflammatory effects, although, whether estrogens operate via regulation of their synthesis is as of yet uncertain. 
Sex difference in platelet function

Platelets not only participate in vascular homeostasis but also contribute to the development of thrombotic events and play a critical role in the pathogenesis of atherosclerosis and CVDs. In this capacity, platelets provide an active surface for pro-coagulant reactions, expressing membrane receptors that affect plateletplatelet and platelet-vessel wall interactions, and releasing vasoactive substances and mitogenic cytokines (von Hundelshausen et al. 2007, Ruggeri \& Mendolicchio 2007). There is evidence that sex hormones, especially estrogen, regulate platelet function. The presence of the ERs, ER $\alpha$ and ER $\beta$, in platelets and their precursors, megakaryocytes (Jayachandran \& Miller 2003, Bord et al. 2004), is thought to underlie the capacity of estrogen to regulate platelet function in a genomic and nongenomic manner, although $\operatorname{ER} \beta$ appears to be the main receptor involved (Khetawat et al. 2000, Bord et al. 2004).

Ex vivo ADP-mediated platelet aggregation and ATP secretion in vitro are higher in platelets from postmenopausal women compared with premenopausal women and $17 \beta$ estradiol, medroxyprogesterone, or MHT suppresses this increase (Nakano et al. 1998). In addition, ADP-induced aggregation is greater in platelets isolated from male compared with female rats, and castration reduces aggregation in males but increases aggregation in females (Johnson et al. 1977). Also, while aggregation decreases with maturity in female pigs, the opposite is true in male pigs (Jayachandran \& Miller 2002). These results are in concordance with human studies supporting the importance of timing of the initiation of MHT. It has been reported that the benefit of treatment only occurs in younger postmenopausal women and this benefit disappears with age (Manson et al. 2006, 2007); an effect that may relate to the action of estrogens on platelets. The Kronos Early Estrogen Prevention Study (KEEPS), currently in progress, was embarked upon to directly address the timing issue, and will assess the antiatherosclerotic effects of conjugated equine estrogens alone and in combination with progesterone transdermally administrated in recently postmenopausal women (Harman et al. 2005). These studies should explain, at least in part, the controversy generated by some trials showing that MHT does not confer protection from CVD in postmenopausal women (Manson et al. 2003, Anderson et al. 2004).

Depletion of female sex hormones has been described to induce numerous changes in platelet reactivity; effects that are reversed following restoration of estrogen levels including increases in platelet aggregation and dense body ATP secretion (Jayachandran et al. 2003, 2005a), increased expression of CD40 and its ligand (Jayachandran et al. 2005b), increased platelet turnover, increase in ER-associated heat shock proteins (HSP70 and HSP90), matrix metalloproteinase-2 (which activates platelet aggregation and adhesion (Sawicki et al. 1997)), and platelet-derived growth factor-BB (Jayachandran \& Miller 2002, 2003, Jayachandran et al. 2003). Many of these actions could contribute to the increased proliferative arterial response to injury that has been identified in ovariectomized animals (Bracamonte et al. 2002).
Many of the anti-aggregatory actions of estrogens on platelets can be attributed to an indirect action of these hormones on the endothelium, in particular via release of the endothelial factors $\mathrm{NO}$ and $\mathrm{PGI}_{2}$, known to reduce platelet aggregation and adhesion. Whether EDHF might also play a role in this endothelium-dependent regulation is currently unknown. In vitro, $17 \beta$-estradiol-induced decreases in platelet aggregation have been associated with increased NO activity, as evidenced by elevated cGMP level expression in human platelets (Nakano et al. 1998), but also to increases in plasma levels of the stable $\mathrm{PGI}_{2}$ metabolite 6-keto-PGF1 $\alpha$ (Nakano et al. 2002).

Yet, a beneficial effect of female sex steroids on platelet reactivity remains controversial since estrogen can, under certain circumstances, induce a pro-aggregatory phenotype. Several studies show higher ex vivo platelet aggregation of platelets of female over male animals (Elam et al. 1980, Durand \& Blache 1996) and women than men (Kelton et al. 1982, Haque et al. 2001). In addition, 17 $\beta$-estradiol treatment and MHT increase the number of circulating activated platelets in postmenopausal women (Thijs et al. 2002); an effect that may relate to estrogen-induced increases in bone marrow megakaryocyte and pro-platelet formation, and platelet release in humans (Bord et al. 2000, Nagata et al. 2003). A pro-aggregatory action of female sex hormones is also supported by the finding that $17 \beta$-estradiol increases tissue factor (TF), a primary initiator of the coagulation pathway, mRNA and protein levels in porcine platelets (Jayachandran et al. 2005b). This effect becomes more significant when one considers that the TF pathway inhibitor (an inhibitor of TF-dependent secretion) is reduced by estrogen treatment in endothelial cells and in postmenopausal women using oral contraceptives (Luyer et al. 2001). Interestingly, unlike the potential pathways that might be implicated in the anti-aggregatory effects of estrogen, thrombin-induced platelet aggregation and activation of integrin $\alpha(\mathrm{IIb}) \beta 3$ by $17 \beta$-estradiol is mediated through ER $\beta$ (Moro et al. 2005).

Just as endothelial factors have been implicated in the beneficial effects of estrogens on platelet reactivity, some studies also support a role for these very same factors in the detrimental effects on platelet function. Surprisingly, the release of $\mathrm{PGI}_{2}$ is greater in platelets from ovariectomized pigs compared with male and female pigs (Miller et al. 1999). While, in contrast, endothelial cell $\mathrm{PGI}_{2}$ production is decreased by physiological doses of female sex hormones (17 $\beta$-estradiol, progesterone or combined treatment; Berge et al. 1990). In addition, certain progestins reduce the anti-aggregatory effect of endothelial cells by decreasing the expression of eNOS and the production of NO (Zerr-Fouineau et al. 2007). All these negative effects of sex hormones on platelet function likely contribute to the increased risk of thrombosis shown in postmenopausal women using MHT. Thus, while it is clear that estrogens can exert antiaggregatory actions and that the endothelium is likely to play an important role in this response, the evidence is equivocal in terms of which endothelial mediator might be important in mediating this effect. In addition, another point of interest is that 
it is not only the female sex hormones that alter platelet activity, but also androgens have been shown to increase the production and reactivity of platelets (Shapiro et al. 1999, Weidemann \& Hanke 2002). What role EDHF might have to play in mediating the effects of sex hormones on platelet reactivity has not been extensively studied, but below we have reviewed the evidence that EDHF might play a role.

C-type natriuretic peptide CNP inhibits plateletleukocyte interactions by downregulating P-selectin expression and preventing thrombin-induced platelet aggregation of human blood (Scotland et al. 2005c). This study taken together with the anti-inflammatory effects described above, suggests that CNP likely represents an important antiatherogenic endothelial mediator. However, further studies are needed to confirm whether the effects of estrogens on platelets are due to CNP activity.

Hydrogen peroxide Some studies have demonstrated that $\mathrm{H}_{2} \mathrm{O}_{2}$ has a pro-thrombotic influence on the vascular wall. $\mathrm{H}_{2} \mathrm{O}_{2}$ induces platelet aggregation (Li et al. 2007), potentiates thrombin-induced platelet aggregation (Naseem \& Bruckdorfer 1999), and is involved in the enhancement of $\mathrm{Ca}^{2+}$ mobilization observed in platelets from diabetic patients which results in platelet hyperactivity (Redondo et al. 2005). These findings suggest a detrimental effect, if anything, of $\mathrm{H}_{2} \mathrm{O}_{2}$ on platelet function, and in combination with the proinflammatory effects of $\mathrm{H}_{2} \mathrm{O}_{2}$ described above, suggest that it acts in a pro-atherogenic manner rather than in an antiatherogenic manner (unlike EDHF).

Epoxyeicosatrienoic acids EETs inhibit platelet aggregation (Fitzpatrick et al. 1986, Jiang et al. 2004) and platelet adhesion to endothelial cells. This is thought to be mediated by EET-induced platelet hyperpolarization and inhibition of P-selectin expression (Krotz et al. 2004). However, as with CNP, there have been no studies to date directly assessing whether EET synthesis might underlie the beneficial effects of estrogens on platelet function.

\section{Sex differences in vessel repair}

Endothelial damage is a crucial event in the development of vascular diseases such as atherosclerosis, vein-graft atherosclerosis and angioplasty-induced restenosis (Ip et al. 1990). Many studies suggest that estrogen replacement therapy reduces the number of coronary events after coronary angioplasty in postmenopausal women (O'Brien et al. 1996, O'Keefe et al. 1997, Khan et al. 2000). However, others investigating directly the relationship between MHT with $17 \beta$-estradiol alone or in combination with progesterone have shown no benefit on the progression of atherosclerosis (bu-Halawa et al. 1998, Herrington et al. 2000, Hodis et al. 2003). However, these negative studies have been conducted, invariably, in older postmenopausal women with pre-existing stenoses and, as mentioned previously, there is a growing understanding that timing of treatment post menopause onset determines whether hormonal treatment is largely beneficial or not (Manson et al. 2006, 2007). However, in postmenopausal women with no evidence of preexisting vascular disease, $17 \beta$-estradiol treatment is associated with reduced progression of carotid artery atherosclerosis and, more recently, this has been further substantiated by the demonstration that those women with the highest free estradiol levels were those with the least progression of atherosclerosis (Karim et al. 2008).

Mechanistically, there is support for the concept that estrogens might reduce the atherosclerotic burden by inhibiting hyperplasia. In a porcine model of restenosis, local delivery of $17 \beta$-estradiol decreases neointimal hyperplasia after coronary angioplasty without stent implantation (Chandrasekar \& Tanguay 2000). Also, administration of this hormone enhances re-endothelialization and endothelial function in rats and pigs and reduces intimal hyperplasia after percutaneous transluminal coronary angioplasty (Krasinski et al. 1997, Concina et al. 2000, Chandrasekar et al. 2001, Kyriakides et al. 2006). Furthermore, estrogen-coated stents are associated with reduced neointimal formation in porcine models (New et al. 2002) and in humans (Abizaid et al. 2004). In addition, neointimal formation in response to balloon injury of the rat carotid artery is attenuated in females compared with males (Chen et al. 1996). Moreover, ovariectomy is associated with a greater increase of neointima formation, and $17 \beta$-estradiol treatment inhibits myointimal proliferation after injury (Chen et al. 1996, Oparil et al. 1999, Bakir et al. 2000). Taken together, the combined effects of enhancing endothelial formation but repressing smooth muscle proliferation have clear beneficial effects in limiting the atherosclerotic burden in the damaged blood vessel.

Migration and proliferation of vascular smooth muscle cells in vascular tissue are two important events for development of myointimal thickening after vascular injury (Libby et al. 1992, Newby \& Zaltsman 2000). In cell culture, 17 $\beta$-estradiol inhibits the migration and proliferation of vascular smooth muscle cells of rodents (Kolodgie et al. 1996, Akishita et al. 1997) and humans (Dai-Do et al. 1996). It is generally accepted that proliferation of smooth muscle cells from the media is involved in intimal hyperplasia; however, it has been suggested that the bone marrow could also supply circulating vascular progenitor smooth muscle and endothelial cells. Indeed, 17 $\beta$ estradiol enhances activation and recruitment of endothelial progenitor cells and contributes to improved neovascularization preserving cardiac function after myocardial infarction (Strehlow et al. 2003, Iwakura et al. 2006). It is thought that this favorable effect is exerted predominantly through ER $\alpha$ and to a lesser extent through ER $\beta$ (Hamada et al. 2006), perhaps with the involvement of eNOS (Iwakura et al. 2006). The possibility that estrogen-induced modulation of EDHF activity might underlie these effects is reviewed below.

Gap junctions Gap junctions may play a role in the response to vessel injury since $\mathrm{Cx} 43$ expression is enhanced in smooth muscle cells of atherosclerotic human, murine, and rodent 


\section{Gap junctions}

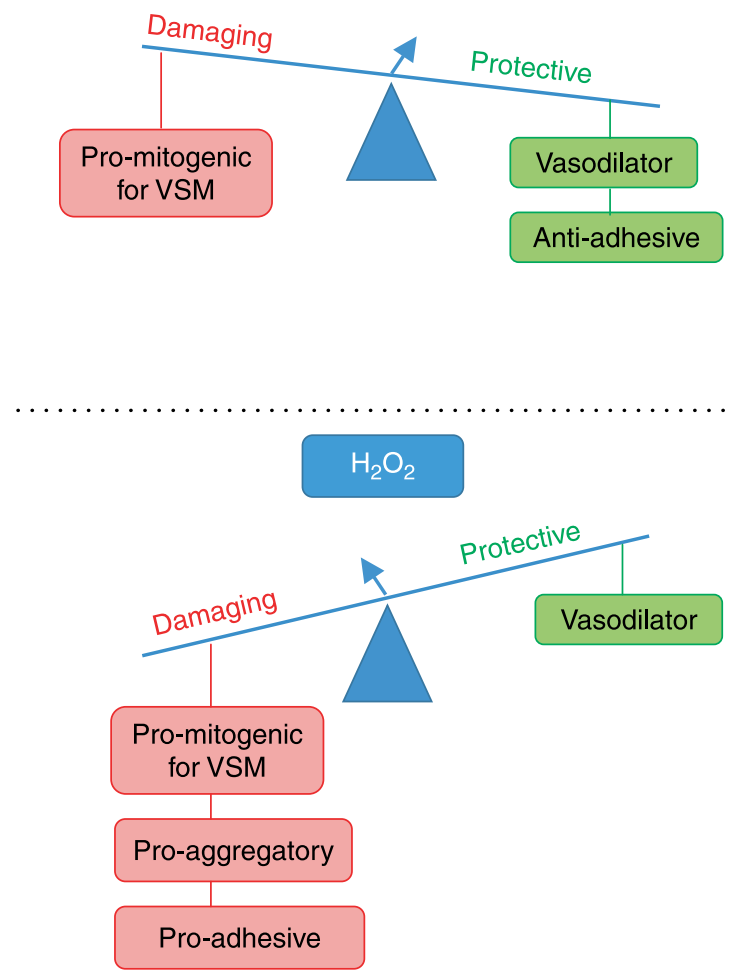

\section{Epoxyeicosatrienoic acids}

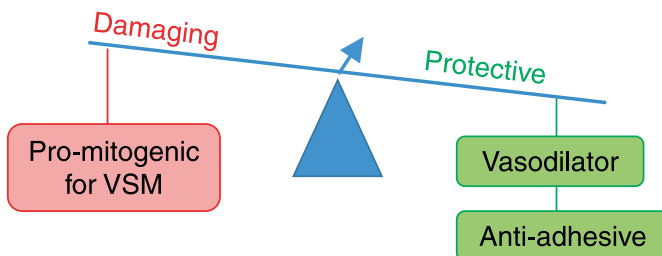

Anti-aggregatory

Figure 1 Impact of estrogen-induced changes in gap junctions, epoxyeicosatrienoic acids, $\mathrm{H}_{2} \mathrm{O}_{2}$, and C-type natriuretic peptide on vascular homeostasis.

arteries (Blackburn et al. 1995, Yeh et al. 1997, Kwak et al. 2002). Moreover, a critical role for $\mathrm{Cx} 43$ has been reported in human saphenous vein during the development of intimal hyperplasia (Deglise et al. 2005) and restenosis (Plenz et al. 2004) and $\mathrm{Cx} 43$ decreases smooth muscle cell proliferation and limits neointima formation after vascular injury
(Chadjichristos et al. 2006). Conversely, regeneration of the endothelium following carotid artery injury in rats, a process essential for wound healing, is associated with increasing expression of $\mathrm{Cx} 37, \mathrm{Cx} 40$, and $\mathrm{Cx} 43$ (Yeh et al. 2000). More detailed investigations of the significance of altered connexin expression is required before any clear consensus on the role

Table 1 The effect of estrogens on the vascular expression/synthesis of some of the main candidates for endothelium-derived hyperpolarizing factor (EDHF)

\section{Effect of estrogen on expression/synthesis}

\section{EDHF candidate}

Myoendothelial gap junctions

$\mathrm{CNP}$

$\mathrm{H}_{2} \mathrm{O}_{2}$

EETs

$\mathrm{NC}$, no change.

\section{References}

Liu et al. (2002), Xu et al. (2002) and Nawate et al. (2005) Sokoya et al. (2007)

Huang et al. (1996), Acuff et al. (1997) and Stepan et al. (2000)

Felty et al. (2005) and Felty (2006)

Miller et al. (2007b)

Huang et al. (2004) and Sun et al. (2007) 
of gap junction expression in mediating the beneficial effect of estrogens in vessel repair can be made.

C-type natriuretic peptide CNP overexpression by adenoviral gene transfer in rabbit vein grafts accelerates re-endothelialization and dramatically reduces the intima formation that develops when it is grafted to the carotid artery (Ohno et al. 2002). Also, CNP inhibits vascular smooth muscle migration and proliferation (Cahill \& Hassid 1991, Furuya et al. 1991). Taken together, these studies suggest that endothelium-derived CNP facilitates repair after vascular injury although again further investigations are required to determine whether CNP might underlie the effects of estrogens.

Hydrogen peroxide In general, reactive oxygen species participate in processes such as growth and migration of vascular smooth muscle cells, which contribute to the development of atherosclerosis. In particular, $\mathrm{H}_{2} \mathrm{O}_{2}$ has been described as a proliferative mediator and an inducer of apoptos is (Konishi et al. 2004, Wang \& Huang 2005) and it has been used as a tool to induce vascular injury. As such it is unlikely that this mediator underlies the beneficial effects of estrogens in vessel injury.

Epoxyeicosatrienoic acids Exogenous ETTs inhibit vascular smooth muscle migration in response to growth factors and overexpression of CYP2J2 in these cells attenuates the migratory effect (Sun et al. 2002). In human vascular endothelial cells, overexpression of CYP2C9, or administration of EETs, increases cell proliferation (Michaelis et al. 2003). Together this data suggests a beneficial profile for EETs as enhances of endothelial but suppressors of smooth muscle cell proliferation. However, EETs have also been shown to induce cell proliferation in smooth muscle cells (Graber et al. 1997, Potente et al. 2002) an effect thought to contribute to the pro-angiogenic effects of EETs confirmed by several studies (Fleming 2007) and thus it is uncertain at present whether alterations in EET expression might be beneficial or pathogenic in vessel injury.

\section{Summary}

The existence of sex differences in CVD has suggested that sex hormones may proffer cardiovascular protection to females. The endothelium plays a crucial role in vascular homeostasis mediating the effects of endothelial-derived factors that are regulated by sex hormones (in particular estrogen). These effects thought to play an important role in cardioprotection observed in younger (premenopausal) women. Besides the regulatory role of sex hormones on vascular tone, estrogen also modulates the recruitment of circulating cells, platelet function, and several processes in vascular repair after injury. While $\mathrm{NO}$ and $\mathrm{PGI}_{2}$ are well characterized in this regard, the significance of EDHF is increasing (despite its identity still being controversial) with respect to its vasodilator activity and its role as a vasoprotective mediator, particularly in females. In this review, we have highlighted that EDHF is not only a potent vasodilator but is also implicated in several aspects of cardiovascular inflammation, platelet function, and vascular repair, and therefore this factor may represent an endogenous protective mechanism against atherosclerosis that is more active in females than males. Not all putative EDHFs described in this review possess beneficial effects in terms of the atherogenic processes, but it is important to bear in mind that the vast majority of the studies were carried out in male animals and subjects, in which $\mathrm{NO}$ and $\mathrm{PGI}_{2}$ are the predominant endothelial factors and therefore the positive effects of EDHF might have been overlooked. Nonetheless, in terms of anti-atherogenic potential of the proposed EDHF candidates, it appears as if CNP possesses the most appropriate bioactive profile (Fig. 1, Table 1) since it not only reduces vascular smooth muscle tone and proliferation, but also leukocyte and platelet reactivity and promotes endothelial growth. In sum, we suggest that sex hormones regulate several atherogenic events in which EDHF appears to play an important role and that this factor might contribute to the cardioprotective phenotype that women enjoy before menopause.

\section{Acknowledgements}

I C V was supported by a British Heart Foundation Project Grant and A J H is supported by a Wellcome Trust Senior Fellowship. The authors declare that there is no conflict of interest that would prejudice the impartiality of this scientific work.

\section{References}

Abizaid A, Albertal M, Costa MA, Abizaid AS, Staico R, Feres F, Mattos LA, Sousa AGMR, Moses J, Kipshidize N et al. 2004 First human experience with the 17-beta-estradiol-eluting stent: the estrogen and stents to eliminate restenosis (EASTER) trial. Journal of the American College of Cardiology 43 1118-1121.

Acuff CG, Huang H \& Steinhelper ME 1997 Estradiol induces C-type natriuretic peptide gene expression in mouse uterus. American Journal of Physiology. Heart and Circulatory Physiology 273 H2672-H2677.

Ahluwalia A \& Hobbs AJ 2005 Endothelium-derived C-type natriuretic peptide: more than just a hyperpolarizing factor. Trends in Pharmacological Sciences 26 162-167.

Akishita M, Ouchi Y, Miyoshi H, Kozaki K, Inoue S, Ishikawa M, Eto M, Toba K \& Orimo H 1997 Estrogen inhibits cuff-induced intimal thickening of rat femoral artery: effects on migration and proliferation of vascular smooth muscle cells. Atherosclerosis 130 1-10.

Anderson GL, Limacher M, Assaf AR, Bassford T, Beresford SA, Black H, Bonds D, Brunner R, Brzyski R, Caan B et al. 2004 Effects of conjugated equine estrogen in postmenopausal women with hysterectomy: the Women's Health Initiative randomized controlled trial. Journal of the American Medical Association 291 1701-1712.

Bakir S, Mori T, Durand J, Chen YF, Thompson JA \& Oparil S 2000 Estrogen-induced vasoprotection is estrogen receptor dependent: evidence from the balloon-injured rat carotid artery model. Circulation 101 2342-2344.

Barber DA, Burnett JC, Jr, Fitzpatrick LA, Sieck GC \& Miller VM 1998 Gender and relaxation to $\mathrm{C}$-type natriuretic peptide in porcine coronary arteries. Journal of Cardiovascular Pharmacology 32 5-11. 
Barrett-Connor E 1997 Sex differences in coronary heart disease: why are women so superior? The 1995 Ancel Keys Lecture Circulation 95 252-264.

Barton M, Beny JL, d'Uscio LV, Wyss T, Noll G \& Luscher TF 1998 Endothelium-independent relaxation and hyperpolarization to C-type natriuretic peptide in porcine coronary arteries. Journal of Cardiovascular Pharmacology 31 377-383.

Bauersachs J, Popp R, Hecker M, Sauer E, Fleming I \& Busse R 1996 Nitric oxide attenuates the release of endothelium-derived hyperpolarising factor. Circulation 94 3341-3347.

Berge LN, Hansen JB, Svensson B, Lyngmo V \& Nordoy A 1990 Female sex hormones and platelet/endothelial cell interactions. Haemostasis $20313-320$.

Blackburn JP, Peters NS, Yeh HI, Rothery S, Green CR \& Severs NJ 1995 Upregulation of Connexin43 gap junctions during early stages of human coronary atherosclerosis. Arteriosclerosis, Thrombosis, and Vascular Biology 15 1219-1228.

Bord S, Vedi S, Beavan SR, Horner A \& Compston JE 2000 Megakaryocyte population in human bone marrow increases with estrogen treatment: a role in bone remodeling? Bone 27 397-401.

Bord S, Frith E, Ireland DC, Scott MA, Craig JI \& Compston JE 2004 Estrogen stimulates differentiation of megakaryocytes and modulates their expression of estrogen receptors alpha and beta. Journal of Cellular Biochemistry 92 249-257.

Bracamonte MP, Rud KS, Owen WG \& Miller VM 2002 Ovariectomy increases mitogens and platelet-induced proliferation of arterial smooth muscle. American Journal of Physiology. Heart and Circulatory Physiology 283 H853-H860.

bu-Halawa SA, Thompson K, Kirkeeide RL, Vaughn WK, Rosales O, Fujisi K, Schroth G, Smalling R \& Anderson HV 1998 Estrogen replacement therapy and outcome of coronary balloon angioplasty in postmenopausal women. American Journal of Cardiology 82 409-413.

Busse R, Edwards G, Feletou M, Fleming I, Vanhoutte PM \& Weston AH 2002 EDHF: bringing the concepts together. Trends in Pharmacological Sciences 23 374-380

Butcher EC 1991 Leukocyte-endothelial cell recognition: three (or more) steps to specificity and diversity. Cell 67 1033-1036.

Cahill PA \& Hassid A 1991 Clearance receptor-binding atrial natriuretic peptides inhibit mitogenesis and proliferation of rat aortic smooth muscle cells. Biochemical and Biophysical Research Communications 179 1606-1613.

Campbell WB 2000 New role for epoxyeicosatrienoic acids as antiinflammatory mediators. Trends in Pharmacological Sciences 21 125-127.

Campbell WB \& Falck JR 2007 Arachidonic acid metabolites as endothelium-derived hyperpolarizing factors. Hypertension 49 590-596.

Campbell WB, Gebremedhin D, Pratt PF \& Harder DR 1996 Identification of epoxyeicosatrienoic acids as endothelium-derived hyperpolarizing factors. Circulation Research 78 415-423.

Campbell SE, Mehan KA, Tunstall RJ, Febbraio MA \& Cameron-Smith D 2003 17beta-estradiol upregulates the expression of peroxisome proliferator-activated receptor alpha and lipid oxidative genes in skeletal muscle. Journal of Molecular Endocrinology 31 37-45.

Card JW, Carey MA, Bradbury JA, DeGraff LM, Morgan DL, Moorman MP, Flake GP \& Zeldin DC 2006 Gender differences in murine airway responsiveness and lipopolysaccharide-induced inflammation. Journal of Immunology 177 621-630.

Caulin-Glaser T, Watson CA, Pardi R \& Bender JR 1996 Effects of 17betaestradiol on cytokine-induced endothelial cell adhesion molecule expression. Journal of Clinical Investigation 98 36-42.

Chadjichristos CE, Matter CM, Roth I, Sutter E, Pelli G, Luscher TF, Chanson M \& Kwak BR 2006 Reduced connexin43 expression limits neointima formation after balloon distension injury in hypercholesterolemic mice. Circulation 113 2835-2843.

Chandrasekar B \& Tanguay JF 2000 Local delivery of 17-beta-estradiol decreases neointimal hyperplasia after coronary angioplasty in a porcine model. Journal of the American College of Cardiology 36 1972-1978.

Chandrasekar B, Nattel S \& Tanguay JF 2001 Coronary artery endothelial protection after local delivery of 17[beta]-estradiol during balloon angioplasty in a porcine model: a potential new pharmacologic approach to improve endothelial function. Journal of the American College of Cardiology 38 $1570-1576$.
Chataigneau T \& Schini-Kerth VB 2005 Vascular effects of ovariectomy and chronic oestrogen treatment in rats: controversy or experimental protocol diversity? British Journal of Pharmacology 144 161-163.

Chataigneau T, Zerr M, Chataigneau M, Hudlett F, Hirn C, Pernot F \& Schini-Kerth VB 2004 Chronic treatment with progesterone but not medroxyprogesterone acetate restores the endothelial control of vascular tone in the mesenteric artery of ovariectomized rats. Menopause $\mathbf{1 1}$ 255-263.

Chauhan S, Rahman A, Nilsson H, Clapp L, MacAllister R \& Ahluwalia A 2003a NO contributes to EDHF-like responses in rat small arteries: a role for NO stores. Cardiovascular Research 57 207-216.

Chauhan SD, Nilsson H, Ahluwalia A \& Hobbs AJ $2003 b$ Release of C-type natriuretic peptide accounts for the biological activity of endotheliumderived hyperpolarizing factor. PNAS 100 1426-1431.

Chen G, Suzuki H \& Weston AH 1988 Acetylcholine releases endotheliumderived hyperpolarizing factor and EDRF from rat blood vessels. British Journal of Pharmacology 95 1165-1174.

Chen SJ, Li H, Durand J, Oparil S \& Chen YF 1996 Estrogen reduces myointimal proliferation after balloon injury of rat carotid artery. Circulation $93577-584$

Cid MC, Kleinman HK, Grant DS, Schnaper HW, Fauci AS \& Hoffman GS 1994 Estradiol enhances leukocyte binding to tumor necrosis factor (TNF)stimulated endothelial cells via an increase in TNF-induced adhesion molecules E-selectin, intercellular adhesion molecule type 1, and vascular cell adhesion molecule type 1. Journal of Clinical Investigation 93 17-25.

Concina P, Sordello S, Barbacanne MA, Elhage R, Pieraggi MT, Fournial G, Plouet J, Bayard F \& Arnal JF 2000 The mitogenic effect of 17beta-estradiol on in vitro endothelial cell proliferation and on in vivo reendothelialization are both dependent on vascular endothelial growth factor. Journal of Vascular Research 37 202-208.

Csanyi G, Bauer M, Dietl W, Lomnicka M, Stepuro T, Podesser BK \& Chlopicki S 2006 Functional alterations in NO, PGI2 and EDHF pathways in the aortic endothelium after myocardial infarction in rats. European Journal of Heart Failure 8 769-776.

Dai-Do D, Espinosa E, Liu G, Rabelink TJ, Julmy F, Yang Z, Mahler F \& Luscher TF 1996 17ß-Estradiol inhibits proliferation and migration of human vascular smooth muscle cells: similar effects in cells from postmenopausal females and in males. Cardiovascular Research 32 980-985.

Deglise S, Martin D, Probst H, Saucy F, Hayoz D, Waeber G, Nicod P, Ris HB, Corpataux JM \& Haefliger JA 2005 Increased connexin 43 expression in human saphenous veins in culture is associated with intimal hyperplasia. Journal of Vascular Research 41 1043-1052.

Di WL, Lachelin GCL, McGarrigle HHG, Thomas NSB \& Becker DL 2001 Oestriol and oestradiol increase cell to cell communication and connexin 43 protein expression in human myometrium. Molecular Human Reproduction 7 671-679.

Durand P \& Blache D 1996 Enhanced platelet thromboxane synthesis and reduced macrophage-dependent fibrinolytic activity related to oxidative stress in oral contraceptive-treated female rats. Atherosclerosis 121 205-216.

Eckhoff DE, Bilbao G, Frenette L, Thompson JA \& Contreras JL 2002 17Beta-estradiol protects the liver against warm ischemia/reperfusion injury and is associated with increased serum nitric oxide and decreased tumor necrosis factor-alpha. Surgery 132 302-309.

Edwards G \& Weston AH 2004 Potassium and potassium clouds in endothelium-dependent hyperpolarizations. Pharmacological Research 49 535-541.

Elam MB, Lipscomb GE, Chesney CM, Terragno DA \& Terragno NA 1980 Effect of synthetic estrogen on platelet aggregation and vascular release of PGI2-like material in the rabbit. Prostaglandins 20 1039-1051.

Faddy HM, Robinson JA, Lee WJ, Holman NA, Monteith GR \& RobertsThomson SJ 2006 Peroxisome proliferator-activated receptor [alpha] expression is regulated by estrogen receptor [alpha] and modulates the response of MCF-7 cells to sodium butyrate. International Journal of Biochemistry \& Cell Biology 38 255-266.

Fang X, Moore SA, Stoll LL, Rich G, Kaduce TL, Weintraub NL \& Spector AA 1998 14,15-Epoxyeicosatrienoic acid inhibits prostaglandin E2 production in vascular smooth muscle cells. American Journal of Physiology $\mathbf{2 7 5}$ H2113-H2121. 
Feletou M \& Vanhoutte PM 2006 Endothelium-derived hyperpolarizing factor: where are we now? Arteriosclerosis, Thrombosis, and Vascular Biology 26 $1215-1225$

Felty Q 2006 Estrogen-induced DNA synthesis in vascular endothelial cells is mediated by ROS signaling. BMC Cardiovascular Disorders 616.

Felty Q, Xiong WC, Sun D, Sarkar S, Singh KP, Parkash J \& Roy D 2005 Estrogen-induced mitochondrial reactive oxygen species as signal-transducing messengers. Biochemistry 44 6900-6909.

Fitzpatrick FA, Ennis MD, Baze ME, Wynalda MA, McGee JE \& Liggett WF 1986 Inhibition of cyclooxygenase activity and platelet aggregation by epoxyeicosatrienoic acids. Influence of stereochemistry. Journal of Biological Chemistry 261 15334-15338.

Fleming I 2007 Epoxyeicosatrienoic acids, cell signaling and angiogenesis. Prostaglandins and other Lipid Mediators 82 60-67.

Fleming I \& Busse R 2006 Endothelium-derived epoxyeicosatrienoic acids and vascular function. Hypertension 47 629-633.

Fleming I, Michaelis UR, Bredenkotter D, Fisslthaler B, Dehghani F, Brandes RP \& Busse R 2001 Endothelium-derived hyperpolarizing factor synthase (Cytochrome $\mathrm{P} 4502 \mathrm{C} 9$ ) is a functionally significant source of reactive oxygen species in coronary arteries. Circulation Research 88 44-51.

Fowkes RC \& McArdle CA 2000 C-type natriuretic peptide: an important neuroendocrine regulator? Prostaglandins and other Lipid Mediators $\mathbf{1 1}$ 333-338.

Furchgott RF \& Vanhoutte PM 1989 Endothelium-derived relaxing and contracting factors. FASEB Journal 3 2007-2018.

Furuya M, Yoshida M, Hayashi Y, Ohnuma N, Minamino N, Kangawa K \& Matsuo H 1991 C-type natriuretic peptide is a growth inhibitor of rat vascular smooth muscle cells. Biochemical and Biophysical Research Communications 177 927-931.

Gabriels JE \& Paul DL 1998 Connexin43 is highly localized to sites of disturbed flow in rat aortic endothelium but connexin 37 and connexin 40 are more uniformly distributed. Circulation Research 83 636-643.

Gao H, Liang M, Bergdahl A, Hamren A, Lindholm MW, hlman-Wright K \& Nilsson BO 2006 Estrogen attenuates vascular expression of inflammation associated genes and adhesion of monocytes to endothelial cells. Inflammation Research 55 349-353.

Garland CJ, Plane F, Kemp BK \& Cocks TM 1995 Endothelium-dependent hyperpolarization: a role in the control of vascular tone. Trends in Pharmacological Sciences 16 23-30.

Gerber RT, Anwar MA \& Poston L 1998 Enhanced acetylcholine induced relaxation in small mesenteric arteries from pregnant rats: an important role for endothelium-derived hyperpolarizing factor (EDHF). British Journal of Pharmacology 125 455-460.

Graber MN, Alfonso A \& Gill DL 1997 Recovery of $\mathrm{Ca}^{2+}$ pools and growth in $\mathrm{Ca}^{2+}$ pool-depleted cells is mediated by specific epoxyeicosatrienoic acids derived from arachidonic acid. Journal of Biological Chemistry 272 29546-29553.

Granger DN 1988 Role of xanthine oxidase and granulocytes in ischemiareperfusion injury. American Journal of Physiology 255 H1269-H1275.

Griffith TM 2004 Endothelium-dependent smooth muscle hyperpolarization: do gap junctions provide a unifying hypothesis? British Journal of Pharmacology 141 881-903.

Hama N, Itoh H, Shirakami G, Suga S, Komatsu Y, Yoshimasa T, Tanaka I, Mori K \& Nakao K 1994 Detection of C-type natriuretic peptide in human circulation and marked increase of plasma CNP level in septic shock patients. Biochemical and Biophysical Research Communications 198 $1177-1182$

Hamada H, Kim MK, Iwakura A, Ii M, Thorne T, Qin G, Asai J, Tsutsumi Y, Sekiguchi H, Silver $M$ et al. 2006 Estrogen receptors $\alpha$ and $\beta$ mediate contribution of bone marrow-derived endothelial progenitor cells to functional recovery after myocardial infarction. Circulation 114 2261-2270.

Haque SF, Matsubayashi H, Izumi S, Sugi T, Arai T, Kondo A \& Makino T 2001 Sex difference in platelet aggregation detected by new aggregometry using light scattering. Endocrine Journal 48 33-41.

Harman SM, Brinton EA, Cedars M, Lobo R, Manson JE, Merriam GR, Miller VM, Naftolin F \& Santoro N 2005 KEEPS: The Kronos Early Estrogen Prevention Study. Climacteric 8 3-12.
Herrington DM, Reboussin DM, Brosnihan KB, Sharp PC, Shumaker SA, Snyder TE, Furberg CD, Kowalchuk GJ, Stuckey TD, Rogers WJ et al. 2000 Effects of estrogen replacement on the progression of coronary-artery atherosclerosis. New England Journal of Medicine 343 522-529.

Hobbs A, Foster P, Prescott C, Scotland R \& Ahluwalia A 2004 Natriuretic peptide receptor-C regulates coronary blood flow and prevents myocardial ischemia/reperfusion injury: novel cardioprotective role for endotheliumderived C-type natriuretic peptide. Circulation 110 1231-1235.

Hodis HN, Mack WJ, Azen SP, Lobo RA, Shoupe D, Mahrer PR, Faxon DP, Cashin-Hemphill L, Sanmarco ME, French WJ et al. 2003 Hormone therapy and the progression of coronary-artery atherosclerosis in postmenopausal women. New England Journal of Medicine 349 535-545.

Hsia J, Langer RD, Manson JE, Kuller L, Johnson KC, Hendrix SL, Pettinger M, Heckbert SR, Greep N, Crawford S et al. 2006 Conjugated equine estrogens and coronary heart disease: the Women's Health Initiative. Archives of Internal Medicine 166 357-365.

Huang H, Acuff CG \& Steinhelper ME 1996 Isolation, mapping, and regulated expression of the gene encoding mouse C-type natriuretic peptide. American Journal of Physiology. Heart and Circulatory Physiology 271 H1565-H1575.

Huang A, Wu Y, Sun D, Koller A \& Kaley G 2001 Effect of estrogen on flowinduced dilation in NO deficiency: role of prostaglandins and EDHF. Journal of Applied Physiology 91 2561-2566.

Huang A, Sun D, Wu Z, Yan C, Carroll MA, Jiang H, Falck JR \& Kaley G 2004 Estrogen elicits cytochrome P450 - mediated flow-induced dilation of arterioles in NO deficiency: role of PI3K-Akt phosphorylation in genomic regulation. Circulation Research 94 245-252.

Huang A, Sun D, Jacobson A, Carroll MA, Falck JR \& Kaley G 2005 Epoxyeicosatrienoic acids are released to mediate shear stress-dependent hyperpolarization of arteriolar smooth muscle. Circulation Research 96 376-383

Von Hundelshausen P, Petersen F \& Brandt E 2007 Platelet-derived chemokines in vascular biology. Thrombosis and Haemostasis 97 704-713.

Ignarro LJ, Buga GM, Wood KS, Byrns RE \& Chaudhuri G 1987 Endothelium-derived relaxing factor produced and released from artery and vein is nitric oxide. PNAS $\mathbf{8 4}$ 9265-9269.

Ip JH, Fuster V, Badimon L, Badimon J, Taubman MB \& Chesebro JH 1990 Syndromes of accelerated atherosclerosis: role of vascular injury and smooth muscle cell proliferation. Journal of the American College of Cardiology $\mathbf{1 5}$ $1667-1687$.

Iwakura A, Shastry S, Luedemann C, Hamada H, Kawamoto A, Kishore R, Zhu Y, Qin G, Silver M, Thorne T et al. 2006 Estradiol enhances recovery after myocardial infarction by augmenting incorporation of bone marrowderived endothelial progenitor cells into sites of ischemia-induced neovascularization via endothelial nitric oxide synthase-mediated activation of matrix metalloproteinase-9. Circulation 113 1605-1614.

Jara PI, Boric MP \& Saez JC 1995 Leukocytes express Connexin 43 after activation with lipopolysaccharide and appear to form gap junctions with endothelial cells after ischemia-reperfusion. PNAS 92 7011-7015.

Jayachandran M \& Miller VM 2002 Ovariectomy upregulates expression of estrogen receptors, NOS, and HSPs in porcine platelets. American Journal of Physiology. Heart and Circulatory Physiology 283 H220-H226.

Jayachandran M \& Miller VM 2003 Human platelets contain estrogen receptor alpha, caveolin-1 and estrogen receptor associated proteins. Platelets 14 75-81.

Jayachandran M, Owen WG \& Miller VM 2003 Effects of ovariectomy on aggregation, secretion, and metalloproteinases in porcine platelets. American Journal of Physiology. Heart and Circulatory Physiology 284 H1679-H1685.

Jayachandran M, Mukherjee R, Steinkamp T, LaBreche P, Bracamonte MP, Okano H, Owen WG \& Miller VM 2005a Differential effects of 17betaestradiol, conjugated equine estrogen, and raloxifene on mRNA expression, aggregation, and secretion in platelets. American Journal of Physiology. Heart and Circulatory Physiology 288 H2355-H2362.

Jayachandran M, Sanzo A, Owen WG \& Miller VM 2005b Estrogenic regulation of tissue factor and tissue factor pathway inhibitor in platelets. American Journal of Physiology. Heart and Circulatory Physiology 289 H1908-H1916. 
Jiang H, McGiff JC, Quilley J, Sacerdoti D, Reddy LM, Falck JR, Zhang F, Lerea KM \& Wong PY 2004 Identification of 5,6-trans-epoxyeicosatrienoic acid in the phospholipids of red blood cells. Journal of Biological Chemistry 279 36412-36418.

Johnson M, Ramey E \& Ramwell PW 1977 Androgen-mediated sensitivity in platelet aggregation. American Journal of Physiology. Heart and Circulatory Physiology 232 H381-H385.

Karim R, Hodis HN, Stanczyk FZ, Lobo RA \& Mack WJ 2008 Relationship between serum levels of sex hormones and progression of subclinical atherosclerosis in postmenopausal women. Journal of Clinical Endocrinology and Metabolism 93 131-138.

Kelton JG, Carter CJ, Santos A \& Hirsh J 1982 Sex related differences in platelet function: the effect of aspirin. Blood 59 625-627.

Kenny LC, Baker PN, Kendall DA, Randall MD \& Dunn WR 2002 Differential mechanisms of endothelium-dependent vasodilator responses in human myometrial small arteries in normal pregnancy and preeclampsia. Clinical Science 103 67-73.

Khan MA, Liu MW, Singh D, Pal A, Chio FL, Lawson D \& Dean LS 2000 Long-term (three years) effect of estrogen replacement therapy on major adverse cardiac events in postmenopausal women after intracoronary stenting. American Journal of Cardiology 86 330-333.

Khetawat G, Faraday N, Nealen ML, Vijayan KV, Bolton E, Noga SJ \& Bray PF 2000 Human megakaryocytes and platelets contain the estrogen receptor beta and androgen receptor (AR): testosterone regulates AR expression. Blood 95 2289-2296.

Kolodgie FD, Jacob A, Wilson PS, Carlson GC, Farb A, Verma A \& Virmani R 1996 Estradiol attenuates directed migration of vascular smooth muscle cells in vitro. American Journal of Pathology 148 969-976.

Konishi A, Aizawa T, Mohan A, Korshunov VA \& Berk BC 2004 Hydrogen peroxide activates the Gas6-Axl pathway in vascular smooth muscle cells. Journal of Biological Chemistry 279 28766-28770.

Krasinski K, Spyridopoulos I, Asahara T, van der ZR, Isner JM \& Losordo DW 1997 Estradiol accelerates functional endothelial recovery after arterial injury. Circulation 95 1768-1772.

Krotz F, Riexinger T, Buerkle MA, Nithipatikom K, Gloe T, Sohn HY, Campbell WB \& Pohl U 2004 Membrane potential-dependent inhibition of platelet adhesion to endothelial cells by epoxyeicosatrienoic acids. Arteriosclerosis, Thrombosis, and Vascular Biology 24 595-600.

Kwak BR, Mulhaupt F, Veillard N, Gros DB \& Mach F 2002 Altered pattern of vascular connexin expression in atherosclerotic plaques. Arteriosclerosis, Thrombosis, and Vascular Biology 22 225-230.

Kyriakides ZS, Lymberopoulos E, Papalois A, Kyrzopoulos S, Dafnomili V, Sbarouni E \& Kremastinos DT 2006 Estrogen decreases neointimal hyperplasia and improves re-endothelialization in pigs. International Journal of Cardiology 113 48-53.

Lang NN, Luksha L, Newby DE \& Kublickiene K 2007 Connexin 43 mediates endothelium-derived hyperpolarizing factor-induced vasodilatation in subcutaneous resistance arteries from healthy pregnant women. American Journal of Physiology. Heart and Circulatory Physiology 292 H1026-H1032.

Larsen BT, Miura H, Hatoum OA, Campbell WB, Hammock BD, Zeldin DC, Falck JR \& Gutterman DD 2006 Epoxyeicosatrienoic and dihydroxyeicosatrienoic acids dilate human coronary arterioles via $\mathrm{BK}(\mathrm{Ca})$ channels: implications for soluble epoxide hydrolase inhibition. American Journal of Physiology. Heart and Circulatory Physiology 290 H491-H499.

Lerner DJ \& Kannel WB 1986 Patterns of coronary heart disease morbidity and mortality in the sexes: a 26-year follow-up of the Framingham population. American Heart Journal 111 383-390.

Levin ER, Gardner DG \& Samson WK 1998 Natriuretic peptides. New England Journal of Medicine 339 321-328.

Lewis MS, Whatley RE, Cain P, McIntyre TM, Prescott SM \& Zimmerman GA 1988 Hydrogen peroxide stimulates the synthesis of platelet-activating factor by endothelium and induces endothelial cell-dependent neutrophil adhesion. Journal of Clinical Investigation 82 2045-2055.

Li S, Li X, Li J, Deng X \& Li Y 2007 Inhibition of oxidative-stress-induced platelet aggregation by androgen at physiological levels via its receptor is associated with the reduction of thromboxane A2 release from platelets. Steroids 72 875-880.
Libby P 2002 Inflammation in atherosclerosis. Nature 420 868-874.

Libby P, Schwartz D, Brogi E, Tanaka H \& Clinton SK 1992 A cascade model for restenosis. A special case of atherosclerosis progression. Circulation $\mathbf{8 6}$ III47-III52.

Liu MY, Hattori Y, Fukao M, Sato A, Sakuma I \& Kanno M 2001 Alterations in EDHF-mediated hyperpolarization and relaxation in mesenteric arteries of female rats in long-term deficiency of oestrogen and during oestrus cycle. British Journal of Pharmacology 132 1035-1046.

Liu MY, Hattori Y, Sato A, Ichikawa R, Zhang XH \& Sakuma I 2002 Ovariectomy attenuates hyperpolarization and relaxation mediated by endothelium-derived hyperpolarizing factor in female rat mesenteric artery: a concomitant decrease in connexin-43 expression. Journal of Cardiovascular Pharmacology 40 938-948.

Liu Y, Zhang Y, Schmelzer K, Lee TS, Fang X, Zhu Y, Spector AA, Gill S, Morisseau C, Hammock BD et al. 2005 The antiinflammatory effect of laminar flow: the role of PPAR $\gamma$, epoxyeicosatrienoic acids, and soluble epoxide hydrolase. PNAS 102 16747-16752.

Lucca JJD, Adeagbo ASO \& Alsip NL 2000 Influence of oestrous cycle and pregnancy on the reactivity of the rat mesenteric vascular bed. Human Reproduction 15 961-968.

Luksha L, Nisell H \& Kublickiene K 2004 The mechanism of EDHFmediated responses in subcutaneous small arteries from healthy pregnant women. American Journal of Physiology. Regulatory, Integrative and Comparative Physiology 286 R1102-R1109.

Luyer MD, Khosla S, Owen WG \& Miller VM 2001 Prospective randomized study of effects of unopposed estrogen replacement therapy on markers of coagulation and inflammation in postmenopausal women. Journal of Clinical Endocrinology and Metabolism 86 3629-3634.

Malek AM, Alper SL \& Izumo S 1999 Hemodynamic shear stress and its role in atherosclerosis. Journal of the American Medical Association 282 2035-2042.

Manson JE, Hsia J, Johnson KC, Rossouw JE, Assaf AR, Lasser NL, Trevisan M, Black HR, Heckbert SR, Detrano R et al. 2003 Estrogen plus progestin and the risk of coronary heart disease. New England Journal of Medicine 349 523-534.

Manson JE, Bassuk SS, Harman SM, Brinton EA, Cedars MI, Lobo R, Merriam GR, Miller VM, Naftolin F \& Santoro N 2006 Postmenopausal hormone therapy: new questions and the case for new clinical trials. Menopause 13 139-147.

Manson JE, Allison MA, Rossouw JE, Carr JJ, Langer RD, Hsia J, Kuller LH, Cochrane BB, Hunt JR, Ludlam SE et al. 2007 Estrogen therapy and coronary-artery calcification. New England Journal of Medicine 356 2591-2602.

Matoba T, Shimokawa H, Nakashima M, Hirakawa Y, Mukai Y, Hirano K, Kanaide H \& Takeshita A 2000 Hydrogen peroxide is an endotheliumderived hyperpolarizing factor in mice. Journal of Clinical Investigation 106 1521-1530.

Matoba T, Shimokawa H, Kubota H, Morikawa K, Fujiki T, Kunihiro I, Mukai Y, Hirakawa Y \& Takeshita A 2002 Hydrogen peroxide is an endothelium-derived hyperpolarizing factor in human mesenteric arteries. Biochemical and Biophysical Research Communications 290 909-913.

McCulloch AI \& Randall MD 1998 Sex differences in the relative contributions of nitric oxide and EDHF to agonist-stimulated endothelium-dependent relaxations in the rat isolated mesenteric arterial bed. British Journal of Pharmacology 123 1700-1706.

Mendelsohn ME \& Karas RH 1999 The protective effects of estrogen on the cardiovascular system. New England Journal of Medicine 340 1801-1811.

Mendelsohn ME \& Karas RH 2005 Molecular and cellular basis of cardiovascular gender differences. Science 308 1583-1587.

Michaelis UR, Fisslthaler B, Medhora M, Harder D, Fleming I \& Busse R 2003 Cytochrome P450 2C9-derived epoxyeicosatrienoic acids induce angiogenesis via cross-talk with the epidermal growth factor receptor. FASEB Journal 17 770-772.

Mikkola TS \& St Clair RW 2002 Estradiol reduces basal and cytokine induced monocyte adhesion to endothelial cells. Maturitas 41 313-319.

Miller VM, Lewis DA \& Barber DA 1999 Gender differences and endothelium- and platelet-derived factors in the coronary circulation. Clinical and Experimental Pharmacology and Physiology 26 132-136. 
Miller AP, Feng W, Xing D, Weathington NM, Blalock JE, Chen YF \& Oparil S 2004 Estrogen modulates inflammatory mediator expression and neutrophil chemotaxis in injured arteries. Circulation 110 1664-1669.

Miller AA, De Silva TM, Jackman KA \& Sobey C 2007a Effect of gender and sex hormones on vascular oxidative stress. Clinical and Experimental Pharmacology and Physiology 34 1037-1043.

Miller AA, Drummond GR, Mast AE, Schmidt HHHW \& Sobey CG $2007 b$ Effect of gender on NADPH-oxidase activity, expression and function in the cerebral circulation: role of estrogen. Stroke 38 2142-2149.

Miura H, Bosnjak JJ, Ning G, Saito T, Miura M \& Gutterman DD 2003 Role for hydrogen peroxide in flow-induced dilation of human coronary arterioles. Circulation Research 92 e31-e40.

Moncada S \& Higgs EA 1991 Endogenous nitric oxide: physiology, pathology and clinical relevance. European Journal of Clinical Investigation 21 361-374.

Moncada S \& Higgs EA 2006 Nitric oxide and the vascular endothelium. Handbook of Experimental Pharmacology 176 213-254.

Moncada S \& Vane JR 1981 Prostacyclin and blood coagulation. Drugs 21 430-437.

Moncada S, Gryglewski R, Bunting S \& Vane JR 1976 An enzyme isolated from arteries transforms prostaglandin endoperoxides to an unstable substance that inhibits platelet aggregation. Nature 263 663-665.

Mori M, Tsukahara F, Yoshioka T, Irie K \& Ohta H 2004 Suppression by 17beta-estradiol of monocyte adhesion to vascular endothelial cells is mediated by estrogen receptors. Life Sciences 75 599-609.

Morikawa K, Shimokawa H, Matoba T, Kubota H, Akaike T, Talukder MAH, Hatanaka M, Fujiki T, Maeda H, Takahashi S et al. 2003 Pivotal role of $\mathrm{Cu}, \mathrm{Zn}$-superoxide dismutase in endothelium-dependent hyperpolarization. Journal of Clinical Investigation 112 1871-1879.

Moro L, Reineri S, Piranda D, Pietrapiana D, Lova P, Bertoni A, Graziani A, Defilippi P, Canobbio I, Torti M et al. 2005 Nongenomic effects of 17betaestradiol in human platelets: potentiation of thrombin-induced aggregation through estrogen receptor beta and Src kinase. Blood 105 115-121.

Mukherjee TK, Dinh H, Chaudhuri G \& Nathan L 2002 Testosterone attenuates expression of vascular cell adhesion molecule-1 by conversion to estradiol by aromatase in endothelial cells: implications in atherosclerosis. PNAS 99 4055-4060.

Muller-Delp JM, Lubahn DB, Nichol KE, Philips BJ, Price EM, Curran EM \& Laughlin MH 2003 Regulation of nitric oxide-dependent vasodilation in coronary arteries of estrogen receptor- $\alpha$-deficient mice. American Journal of Physiology. Heart and Circulatory Physiology 285 H2150-H2157.

Murphy E \& Steenbergen C 2007 Gender-based differences in mechanisms of protection in myocardial ischemia-reperfusion injury. Cardiovascular Research 75 478-486.

Nagata M, Yamamoto H, Shibasaki M, Sakamoto Y \& Matsuo H 2000 Hydrogen peroxide augments eosinophil adhesion via beta2 integrin. Immunology 101 412-418.

Nagata Y, Yoshikawa J, Hashimoto A, Yamamoto M, Payne AH \& Todokoro K 2003 Proplatelet formation of megakaryocytes is triggered by autocrinesynthesized estradiol. Genes and Development 17 2864-2869.

Nakano Y, Oshima T, Matsuura H, Kajiyama G \& Kambe M 1998 Effect of 17-estradiol on inhibition of platelet aggregation in vitro is mediated by an increase in NO synthesis. Arteriosclerosis, Thrombosis, and Vascular Biology 18 961-967.

Nakano Y, Oshima T, Ozono R, Ueda A, Oue Y, Matsuura H, Sanada M, Ohama K, Chayama K \& Kambe M 2002 Estrogen replacement suppresses function of thrombin stimulated platelets by inhibiting $\mathrm{Ca}^{2+}$ influx and raising cyclic adenosine monophosphate. Cardiovascular Research $\mathbf{5 3}$ 634-641.

nand-Srivastava M, Sehl P \& Lowe D 1996 Cytoplasmic domain of natriuretic peptide receptor-C inhibits adenylyl cyclase. Involvement of a pertussis toxin-sensitive G protein. Journal of Biological Chemistry 271 19324-19329.

Naseem KM \& Bruckdorfer KR 1999 The influence of organic peroxides on platelet aggregation and sensitivity to nitric oxide. Platelets 10 146-152.

Nathan L, Pervin S, Singh R, Rosenfeld M \& Chaudhuri G 1999 Estradiol inhibits leukocyte adhesion and transendothelial migration in rabbits in vivo: possible mechanisms for gender differences in atherosclerosis. Circulation Research 85 377-385.
Nawate S, Fukao M, Sakuma I, Soma T, Nagai K, Takikawa O, Miwa S \& Kitabatake A 2005 Reciprocal changes in endothelium-derived hyperpolarizing factor- and nitric oxide-system in the mesenteric artery of adult female rats following ovariectomy. British Journal of Pharmacology 144 178-189.

Neijssen J, Pang B \& Neefjes J 2007 Gap junction-mediated intercellular communication in the immune system. Progress in Biophysics and Molecular Biology 94 207-218.

New G, Moses JW, Roubin GS, Leon MB, Colombo A, Iyer SS, Tio FO, Mehran R \& Kipshidze N 2002 Estrogen-eluting, phosphorylcholinecoated stent implantation is associated with reduced neointimal formation but no delay in vascular repair in a porcine coronary model. Catheterization and Cardiovascular Interventions $\mathbf{5 7}$ 266-271.

Newby AC \& Zaltsman AB 2000 Molecular mechanisms in intimal hyperplasia. Journal of Pathology 190 300-309.

Nilsson BO 2007 Modulation of the inflammatory response by estrogens with focus on the endothelium and its interactions with leukocytes. Inflammation Research 56 269-273.

Node K, Huo Y, Ruan X, Yang B, Spiecker M, Ley K, Zeldin DC \& Liao JK 1999 Anti-inflammatory properties of cytochrome P450 epoxygenasederived eicosanoids. Science 285 1276-1279.

Obata H, Yanagawa B, Tanaka K, Ohnishi S, Kataoka M, Miyahara Y, Ishibashi-Ueda H, Kodama M, Aizawa Y, Kangawa K et al. 2007 CNP infusion attenuates cardiac dysfunction and inflammation in myocarditis. Biochemical and Biophysical Research Communications 356 60-66.

O'Brien JE, Peterson ED, Keeler GP, Berdan LG, Ohman EM, Faxon DP, Jacobs AK, Topol EJ \& Califf RM 1996 Relation between estrogen replacement therapy and restenosis after percutaneous coronary interventions. Journal of the American College of Cardiology 28 1111-1118.

Ohno N, Itoh H, Ikeda T, Ueyama K, Yamahara K, Doi K, Yamashita J, Inoue M, Masatsugu K, Sawada N et al. 2002 Accelerated reendothelialization with suppressed thrombogenic property and neointimal hyperplasia of rabbit jugular vein grafts by adenovirus-mediated gene transfer of C-type natriuretic peptide. Circulation 105 1623-1626.

O'Keefe JH Jr, Kim SC, Hall RR, Cochran VC, Lawhorn SL \& McCallister BD 1997 Estrogen replacement therapy after coronary angioplasty in women. Journal of the American College of Cardiology 29 1-5.

Oparil S, Chen SJ, Chen YF, Durand JN, Allen L \& Thompson JA 1999 Estrogen attenuates the adventitial contribution to neointima formation in injured rat carotid arteries. Cardiovascular Research 44 608-614.

Orshal JM \& Khalil RA 2004 Gender, sex hormones, and vascular tone. American Journal of Physiology. Regulatory, Integrative and Comparative Physiology 286 R233-R249.

O'Sullivan SE, Kendall DA \& Randall MD 2006 Further characterization of the time-dependent vascular effects of delta9-tetrahydrocannabinol. Journal of Pharmacology and Experimental Therapeutics 317 428-438.

Oviedo-Orta E \& Howard Evans W 2004 Gap junctions and connexinmediated communication in the immune system. Biochimica et Biophysica Acta 1662 102-112.

Pak KJ, Geary GG, Duckles SP \& Krause DN 2002 Male-female differences in the relative contribution of endothelial vasodilators released by rat tail artery. Life Sciences 71 1633-1642.

Palmer RM, Ferrige AG \& Moncada S 1987 Nitric oxide release accounts for the biological activity of endothelium-derived relaxing factor. Nature 327 524-526.

Parthasarathi K, Ichimura H, Monma E, Lindert J, Quadri S, Issekutz A \& Bhattacharya J 2006 Connexin 43 mediates spread of $\mathrm{Ca}^{2+}$-dependent proinflammatory responses in lung capillaries. Journal of Clinical Investigation $1162193-2200$

Pascoal IF \& Umans JG 1996 Effect of pregnancy on mechanisms of relaxation in human omental microvessels. Hypertension 28 183-187.

Patel KD, Zimmerman GA, Prescott SM, McEver RP \& McIntyre TM 1991 Oxygen radicals induce human endothelial cells to express GMP-140 and bind neutrophils. Journal of Cell Biology 112 749-759.

Pervin S, Singh R, Rosenfeld ME, Nacab M, Chaudhuri G \& Nathan L 1998 Estradiol suppresses MCP-1 expression in vivo: implications for atherosclerosis. Arteriosclerosis, Thrombosis, and Vascular Biology 18 1575-1582. 
Plenz G, Ko YS, Yeh HI, Eschert H, Sindermann JR, Dorszewski A, Hofnagel O, Robenek H, Breithardt G \& Severs NJ 2004 Upregulation of connexin43 gap junctions between neointimal smooth muscle cells. European Journal of Cell Biology 83 521-530.

Potente M, Michaelis UR, Fisslthaler B, Busse R \& Fleming I 2002 Cytochrome $\mathrm{P} 450$ 2C9-induced endothelial cell proliferation involves induction of mitogen-activated protein (MAP) kinase phosphatase-1, inhibition of the c-Jun N-terminal kinase, and up-regulation of cyclin D1. Journal of Biological Chemistry 277 15671-15676.

Prorock AJ, Hafezi-Moghadam A, Laubach VE, Liao JK \& Ley K 2003 Vascular protection by estrogen in ischemia-reperfusion injury requires endothelial nitric oxide synthase. American Journal of Physiology. Heart and Circulatory Physiology 284 H133-H140.

Punyadeera C, Dassen H, Klomp J, Dunselman G, Kamps R, Dijcks F, Ederveen A, de Goeij A \& Groothuis P 2005 Oestrogen-modulated gene expression in the human endometrium. Cellular and Molecular Life Sciences 62 239-250.

Qian JY, Haruno A, Asada Y, Nishida T, Saito Y, Matsuda T \& Ueno H 2002 Local expression of C-type natriuretic peptide suppresses inflammation, eliminates shear stress-induced thrombosis, and prevents neointima formation through enhanced nitric oxide production in rabbit injured carotid arteries. Circulation Research 91 1063-1069.

Rao RM, Yang L, Garcia-Cardena G \& Luscinskas FW 2007 Endothelialdependent mechanisms of leukocyte recruitment to the vascular wall. Circulation Research 101 234-247.

Redondo PC, Jardin I, Hernandez-Cruz JM, Pariente JA, Salido GM \& Rosado JA 2005 Hydrogen peroxide and peroxynitrite enhance $\mathrm{Ca}^{2+}$ mobilization and aggregation in platelets from type 2 diabetic patients. Biochemical and Biophysical Research Communications 333 794-802.

Ruggeri ZM \& Mendolicchio GL 2007 Adhesion mechanisms in platelet function. Circulation Research 100 1673-1685.

Sakuma I, Liu MY, Sato A, Hayashi T, Iguchi A, Kitabatake A \& Hattori Y 2002 Endothelium-dependent hyperpolarization and relaxation in mesenteric arteries of middle-aged rats: influence of oestrogen. British Journal of Pharmacology 135 48-54.

Sandow SL \& Hill CE 2000 Incidence of myoendothelial gap junctions in the proximal and distal mesenteric arteries of the rat is suggestive of a role in endothelium-derived hyperpolarizing factor-mediated responses. Circulation Research 86 341-346.

Santizo RA, Anderson S, Ye S, Koenig HM \& Pelligrino DA 2000 Effects of estrogen on leukocyte adhesion after transient forebrain ischemia. Stroke $\mathbf{3 1}$ 2231-2235.

Sawicki G, Salas E, Murat J, Miszta-Lane H \& Radomski MW 1997 Release of gelatinase A during platelet activation mediates aggregation. Nature 386 616-619.

Scotland RS, Ahluwalia A \& Hobbs AJ 2005a C-type natriuretic peptide in vascular physiology and disease. Pharmacology and Therapeutics 105 85-93.

Scotland RS, Madhani M, Chauhan S, Moncada S, Andresen J, Nilsson H, Hobbs AJ \& Ahluwalia A $2005 b$ Investigation of vascular responses in endothelial nitric oxide synthase/cyclooxygenase-1 double-knockout mice: key role for endothelium-derived hyperpolarizing factor in the regulation of blood pressure in vivo. Circulation 111 796-803.

Scotland RS, Cohen M, Foster P, Lovell M, Mathur A, Ahluwalia A \& Hobbs AJ 2005 c C-type natriuretic peptide inhibits leukocyte recruitment and plateletleukocyte interactions via suppression of P-selectin expression. PNAS 102 14452-14457.

Selemidis S \& Cocks TM 2002 Endothelium-dependent hyperpolarization as a remote anti-atherogenic mechanism. Trends in Pharmacological Sciences $\mathbf{2 3}$ 213-220.

Shapiro J, Christiana J \& Frishman WH 1999 Testosterone and other anabolic steroids as cardiovascular drugs. American Journal of Therapeutics 6 167-174.

Shimokawa H \& Matoba T 2004 Hydrogen peroxide as an endotheliumderived hyperpolarizing factor. Pharmacological Research 49 543-549.

Shimokawa H \& Morikawa K 2005 Hydrogen peroxide is an endotheliumderived hyperpolarizing factor in animals and humans. Journal of Molecular and Cellular Cardiology 39 725-732.

Shimokawa H, Yasutake H, Fujii K, Owada MK, Nakaike R, Fukumoto Y, Takayanagi T, Nagao T, Egashira K, Fujishima M et al. 1996 The importance of the hyperpolarizing mechanism increases as the vessel size decreases in endothelium-dependent relaxations in rat mesenteric circulation. Journal of Cardiovascular Pharmacology 28 703-711.

Simoncini T, Maffei S, Basta G, Barsacchi G, Genazzani AR, Liao JK \& De CR 2000a Estrogens and glucocorticoids inhibit endothelial vascular cell adhesion molecule- 1 expression by different transcriptional mechanisms. Circulation Research 87 19-25.

Simoncini T, Hafezi-Moghadam A, Brazil DP, Ley K, Chin WW \& Liao JK $2000 \mathrm{~b}$ Interaction of oestrogen receptor with the regulatory subunit of phosphatidylinositol-3-OH kinase. Nature 407 538-541.

Smith KR, Pinkerton KE, Watanabe T, Pedersen TL, Ma SJ \& Hammock BD 2005 Attenuation of tobacco smoke-induced lung inflammation by treatment with a soluble epoxide hydrolase inhibitor. PNAS 102 2186-2191.

Sokoya EM, Burns AR, Marrelli SP \& Chen J 2007 Myoendothelial gap junction frequency does not account for sex differences in EDHF responses in rat MCA. Microvascular Research 74 39-44.

Spiecker M \& Liao J 2006 Cytochrome P450 epoxygenase CYP2J2 and the risk of coronary artery disease. Trends in Cardiovascular Medicine 16 204-208.

Springer TA 1994 Traffic signals for lymphocyte recirculation and leukocyte emigration: the multistep paradigm. Cell 76 301-314.

Squadrito F, Altavilla D, Squadrito G, Campo GM, Arlotta M, Arcoraci V, Minutoli L, Serrano M, Saitta A \& Caputi AP 1997 17Beta-oestradiol reduces cardiac leukocyte accumulation in myocardial ischaemia reperfusion injury in rat. European Journal of Pharmacology 335 185-192.

Stepan H, Walther D, Faber R \& Walther T 2000 Detection of C-type natriuretic peptide in fetal circulation. Journal of Perinatal Medicine $\mathbf{2 8}$ $118-121$.

Stingo AJ, Clavell AL, Heublein DM, Wei CM, Pittelkow MR \& Burnett JC Jr 1992 Presence of C-type natriuretic peptide in cultured human endothelial cells and plasma. American Journal of Physiology. Heart and Circulatory Physiology $263 \mathrm{H} 1318-\mathrm{H} 1321$.

Strehlow K, Werner N, Berweiler J, Link A, Dirnagl U, Priller J, Laufs K, Ghaeni L, Milosevic M, Bohm M et al. 2003 Estrogen increases bone marrow-derived endothelial progenitor cell production and diminishes neointima formation. Circulation 107 3059-3065.

Sun J, Sui X, Bradbury JA, Zeldin DC, Conte MS \& Liao JK 2002 Inhibition of vascular smooth muscle cell migration by cytochrome $\mathrm{P} 450$ epoxygenase-derived eicosanoids. Circulation Research 90 1020-1027.

Sun D, Yan C, Jacobson A, Jiang H, Carroll MA \& Huang A 2007 Contribution of epoxyeicosatrienois acids to flow-induced dilation in arteries of male ER $\alpha$ knockout mice: role of aromatase. American Journal of Physiology. Regulatory, Integrative and Comparative Physiology 293 R1239-R1246.

Suzuki A, Mizuno K, Asada Y, Ino Y, Kuwayama T, Okada M, Mizutani S \& Tomoda Y 1997 Effects of 17beta-estradiol and progesterone on the adhesion of human monocytic THP-1 cells to human female endothelial cells exposed to minimally oxidized LDL. Gynecologic and Obstetric Investigation 44 47-52.

The Women's Health Initiative Steering Committee 2004 Effects of conjugated equine estrogen in postmenopausal women with hysterectomy: the Women's Health Initiative Randomized Controlled Trial. Journal of the American Medical Association 291 1701-1712.

Theis M, de WC, Schlaeger TM, Eckardt D, Kruger O, Doring B, Risau W, Deutsch U, Pohl U \& Willecke K 2001 Endothelium-specific replacement of the connexin 43 coding region by a lacZ reporter gene. Genesis 29 1-13.

Thijs A, van Baal WM, van der Mooren MJ, Kenemans P, Drager AM, Huijgens PC \& Stehouwer CDA 2002 Effects of hormone replacement therapy on blood platelets. European Journal of Clinical Investigation 32 613-618.

Thompson J \& Khalil RA 2003 Gender differences in the regulation of vascular tone. Clinical and Experimental Pharmacology and Physiology 30 1-15.

Ungvari Z, Orosz Z, Labinskyy N, Rivera A, Xiangmin Z, Smith K \& Csiszar A 2007 Increased mitochondrial $\mathrm{H} 2 \mathrm{O} 2$ production promotes endothelial NF-kappaB activation in aged rat arteries. American Journal of Physiology. Heart and Circulatory Physiology 293 H37-H47.

Valen G, Erl W, Eriksson P, Wuttge D, Paulsson G \& Hansson GK 1999 Hydrogen peroxide induces mRNA for tumour necrosis factor alpha in human endothelial cells. Free Radical Research 31 503-512. 
Veerareddy S, Cooke CL, Baker PN \& Davidge ST 2004 Gender differences in myogenic tone in superoxide dismutase knockout mouse: animal model of oxidative stress. American Journal of Physiology. Heart and Circulatory Physiology 287 H40-H45.

Villar IC, Francis S, Webb A, Hobbs AJ \& Ahluwalia A 2006 Novel aspects of endothelium-dependent regulation of vascular tone. Kidney International $\mathbf{7 0}$ 840-853.

Villar IC, Panayiotou CM, Sheraz A, Madhani M, Scotland RS, Nobles M, Kemp-Harper B, Ahluwalia A \& Hobbs AJ 2007a Definitive role for natriuretic peptide receptor-C in mediating the vasorelaxant activity of C-type natriuretic peptide and endothelium-derived hyperpolarising factor. Cardiovascular Research 74 515-525.

Villar IC, Scotland RS, Hobbs AJ \& Ahluwalia A 2007b Sex differences in leukocyte flux: implications for endothelium-derived hyperpolarising factor. Proceedings of the Physiological Society ISSN 1749-6187 (Online) Life Sciences PC138.

Wang YK \& Huang ZQ 2005 Protective effects of icariin on human umbilical vein endothelial cell injury induced by $\mathrm{H} 2 \mathrm{O} 2$ in vitro. Pharmacological Research 52 174-182.

Weidemann W \& Hanke H 2002 Cardiovascular effects of androgens. Cardiovascular Drug Reviews 20 175-198.

Wong CW, Christen T \& Kwak BR 2004 Connexins in leukocytes: shuttling messages? Cardiovascular Research 62 357-367.

Wong CW, Christen T, Roth I, Chadjichristos CE, Derouette JP, Foglia BF, Chanson M, Goodenough DA \& Kwak BR 2006 Connexin37 protects against atherosclerosis by regulating monocyte adhesion. Nature Medicine 12 950-954.

Wray JA \& Bishop-Bailey D 2007 Epoxygenases and PPARs in vascular biology. Experimental Physiology 93 148-154.

Wu Y, Huang A, Sun D, Falck JR, Koller A \& Kaley G 2001 Gender-specific compensation for the lack of NO in the mediation of flow-induced arteriolar dilation. American Journal of Physiology. Heart and Circulatory Physiology $280 \mathrm{H} 2456-\mathrm{H} 2461$.

Xing D, Miller A, Novak L, Rocha R, Chen YF \& Oparil S 2004 Estradiol and progestins differentially modulate leukocyte infiltration after vascular injury. Circulation 109 234-241.
Xu HL, Santizo RA, Baughman VL \& Pelligrino DA 2002 ADP-induced pial arteriolar dilation in ovariectomized rats involves gap junctional communication. American Journal of Physiology. Heart and Circulatory Physiology 283 H1082-H1091.

Xu HL, Ye S, Baughman VL, Feinstein DL \& Pelligrino DA 2005 The role of the glia limitans in ADP-induced pial arteriolar relaxation in intact and ovariectomized female rats. American Journal of Physiology. Heart and Circulatory Physiology 288 H382-H388.

Yada T, Shimokawa H, Hiramatsu O, Haruna Y, Morita Y, Kashihara N, Shinozaki Y, Mori H, Goto M, Ogasawara Y et al. 2006 Cardioprotective role of endogenous hydrogen peroxide during ischemia-reperfusion injury in canine coronary microcirculation in vivo. American Journal of Physiology. Heart and Circulatory Physiology 291 H1138-H1146.

Yeh HI, Lupu F, Dupont E \& Severs NJ 1997 Upregulation of Connexin43 gap junctions between smooth muscle cells after balloon catheter injury in the rat carotid artery. Arteriosclerosis, Thrombosis, and Vascular Biology 17 3174-3184.

Yeh HI, Lai YJ, Chang HM, Ko YS, Severs NJ \& Tsai CH 2000 Multiple connexin expression in regenerating arterial endothelial gap junctions. Arteriosclerosis, Thrombosis, and Vascular Biology 20 1753-1762.

Zahler S, Hoffmann A, Gloe T \& Pohl U 2003 Gap-junctional coupling between neutrophils and endothelial cells: a novel modulator of transendothelial migration. Journal of Leukocyte Biology 73 118-126.

Zarbock A \& Ley K 2008 Mechanisms and consequences of neutrophil interaction with the endothelium. American Journal of Pathology 172 1-7.

Zerr-Fouineau M, Chataigneau M, Blot C \& Schini-Kerth VB 2007 Progestins overcome inhibition of platelet aggregation by endothelial cells by down-regulating endothelial NO synthase via glucocorticoid receptors. FASEB Journal 21 265-273.

\section{Received in final form 28 March 2008 Accepted 31 March 2008 Made available online as an Accepted Preprint 31 March 2008}

